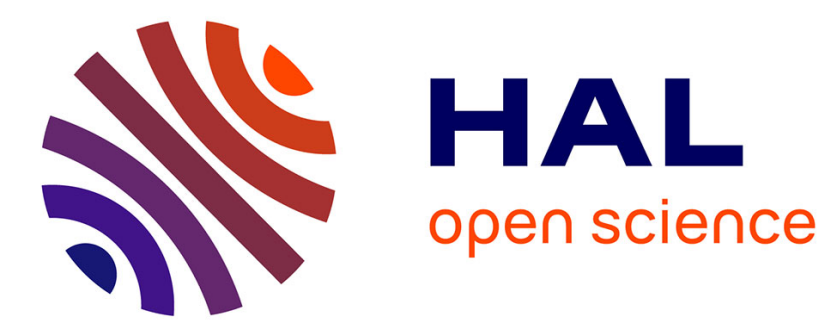

\title{
What seams do we remove in mobile assisted seamless learning? A critical review of the literature
}

\author{
Lung-Hsiang Wong, Chee Kit Looi
}

\section{To cite this version:}

Lung-Hsiang Wong, Chee Kit Looi. What seams do we remove in mobile assisted seamless learning? A critical review of the literature. Computers and Education, 2011, 57(4), pp.2364-2381. hal-00696239

\section{HAL Id: hal-00696239 \\ https://hal.science/hal-00696239}

Submitted on 11 May 2012

HAL is a multi-disciplinary open access archive for the deposit and dissemination of scientific research documents, whether they are published or not. The documents may come from teaching and research institutions in France or abroad, or from public or private research centers.
L'archive ouverte pluridisciplinaire HAL, est destinée au dépôt et à la diffusion de documents scientifiques de niveau recherche, publiés ou non, émanant des établissements d'enseignement et de recherche français ou étrangers, des laboratoires publics ou privés. 


\title{
What Seams Do We Remove in Mobile Assisted Seamless Learning? A Critical Review of the Literature
}

\author{
Lung-Hsiang Wong \& Chee-Kit Looi \\ Learning Sciences Lab., National Institute of Education, Singapore \\ lunghsiang.wong@nie.edu.sg
}

\begin{abstract}
Seamless learning refers to the seamless integration of the learning experiences across various dimensions including formal and informal learning contexts, individual and social learning, and physical world and cyberspace. Inspired by the exposition by Chan, Roschelle, Hsi, Kinshuk, Sharples, Brown, et al. (2006) on the seamless learning model supported by the setting of one or more mobile device per learner, this paper aims to further investigate the meaning of seamless learning and the potential ways to put it in practice. Through a thorough review of recent academic papers on mobile-assisted seamless learning (MSL), we identify ten dimensions that characterize MSL. We believe that such a framework allows us to identify research gaps in the stated area. A practitioner interested in adopting a MSL design or doing a new design can use our analysis to situate the dimensional space where the constraints or parameters of his or her design problem lie, and look at relevant design and research-based evidence of other related MSL systems to refine her own design.
\end{abstract}

Keywords: Teaching/learning strategies; Distributed learning environments; Computer-mediated communication;

Pedagogical issues

\section{Introduction}

Since the notion of seamless learning supported by 1:1 (one-mobile-device-per-learner) setting has been expounded in Chan et al. (2006), a major international synthesis of the topic, there has been a flurry of subsequent relevant discussions within the research community of mobile and ubiquitous learning. Dozens of subsequent academic papers produced by the community cited the notion, though not all of them put it into actual research studies. Chan et al. (2006) define seamless learning as a learning model where a student can learn whenever they are curious in a variety of scenarios and in which they can switch from one scenario or context (such as formal and informal learning, personal and social learning, etc.) to another easily and quickly using the personal device as a mediator. The mobile devices carried by the seamless learners could function as a "learning hub" (Looi, et al., 2009) or the technological interface between learners and their learning environments (Bentley, Shegunshi, \& Scannell, 2010) for experiencing or enacting seamless

Please cite:

Wong, L.-H., \& Looi, C.-K. (2011). What seams do we remove in mobile assisted seamless learning? A critical review of the literature. Computers \& Education, 57(4), 2364-2381. 
learning. In this paper, we refer to seamless learning mediated by 1:1 setting as mobile assisted seamless learning (MSL).

The initial notion of 1:1 refers to the ratio of one computer or one computing device to one student. According to the G1:1 (http://www.g1to1.org/) website, "in one-to-one (1:1) technology enhanced learning (TEL), every learner has a personal computing device that is mobile, wirelessly connected, and enables multimedia input and output." With the availability of several computing devices within access of a student, we broaden it to mean one or more device per learner. The pervasive use of mobile devices means it is feasible to have a " $1: 1,24 \times 7$ " setting that provides anytime access to a learner.

The ubiquitous availability of 1:1 promotes the seamless learning notion that advocates the embodiment of learning into everyday living. The notion of seamless learning advocates "learning anytime, anywhere" and not "learning everytime, everywhere." We do not mean that seamless learners are always doing tasks and pursuing learning especially outside of school. Rather, the goal is to empower and support them to learn wherever and whenever they are stimulated to learn, and not to require them to learn every single second when they are awake.

In this paper, after sharing our thorough review of recent academic papers on mobile-assisted seamless learning (MSL), we identify and unpack ten dimensions that characterize MSL. In turn, we will rise above these "seams to be removed" to discuss how it may inform future MSL researchers or practitioners in refining their learning designs. In short, this paper aims to unpack the connotation and the features of such a learning model, and unravel the potential ways of enacting MSL from research studies.

\section{2. “Seamless Learning” before Chan et al. (2006)}

The term "seamless learning" did not originate from Chan, et al. (2006), and it was initially used without any consideration of technology as an essential component. American College Personnel Association (1994) stresses the importance of linking students' in-class and out-of-class

Please cite:

Wong, L.-H., \& Looi, C.-K. (2011). What seams do we remove in mobile assisted seamless learning? A critical review of the literature. Computers \& Education, 57(4), 2364-2381. 
(but still in-campus) experiences to create seamless learning and academic success. Kuh (1996) further elaborates the notion by extending it to involve off-campus experiences:

"The word seamless suggests that what was once believed to be separate, distinct parts (e.g., in-class and out-of-class, academic and non-academic; curricular and co-curricular, or on-campus and off-campus experiences) are now of one piece, bound together so as to appear whole or continuous. In seamless learning environments, students are encouraged to take advantage of learning resources that exist both inside and outside of the classroom... students are asked to use their life experiences to make meaning of material introduced in classes..." (p.136)

Focusing on integrating formal and informal learning, Kuh's (1996) exposition stimulated further discussions (e.g., Bell, 2000; Seifert, et al., 2008) and inspired further relevant studies (e.g., Smith \& Northrop, 1998) on this learning model, though with varied emphasis. Other researchers added the dimension of learning community (e.g., MacGregor, Tinto, \& Lindbald, 2001; Tinto, 1998) and the intertwining of individual and collaborative learning (e.g., Kazmer, 2005; Skop, 2008) into the notion. A common characteristic of this group of literature is that almost all of them pertain to tertiary education in context. Seamless learning for K-12 students was seriously underexplored.

\section{Seamless Learning Meets WMUTE - 1:1 Technology-Enhanced Learning (TEL)}

With research in Wireless, Mobile and Ubiquitous Technology in Education (WMUTE) ongoing for a decade and through rapid evolution, there is great diversity in the scholars' and educators' conceptual understanding and approaches to harnessing mobile and unbiqitous computing. From the literature on classifications of mobile learning, we observe a variety of classification frameworks being developed - from technical-oriented (Roschelle, 2003; Song, 2007)

Please cite:

Wong, L.-H., \& Looi, C.-K. (2011). What seams do we remove in mobile assisted seamless learning? A critical review of the literature. Computers \& Education, 57(4), 2364-2381. 
to learning theory-based (Naismith, Lonsdale, Vavoula, \& Sharples, 2004) to that of a hybrid techno-pedagogical construct (Patten, Arnedillo-Sánchez, \& Tangney, 2006).

$\mathrm{Yu}$ (2007) combs the development of three generations of mobile learning: the first generation focuses on transferring learning content onto mobile devices (transfer of information and behaviorism); the second generation focuses on pedagogical design (cognitivism and constructivism); and the third generation is characterized by $1: 1$ setting and the use of context-aware technology. Barbosa \& Geyer's (2005) view summarizes the essence of the third generation mobile learning well - it “is about increasing a learner's capability to physically move their own learning environment as they move." This would transform students into genuine "nomadic learners" (Brodersen, Christensen, Grønbæk, Dindler, \& Sundararajah, 2005). Hence, while the first and second generation mobile learning tend to confine the learners in the formal learning (teacher- or expert-planned learning materials or activities) context, third generation mobile learning is creating the impact of stitching the learners' formal and informal learning contexts together to lead towards seamless learning and making their learning experiences more personalized.

Indeed, ready-to-hand, perhaps $24 \times 7$ access of light-weight mobile devices creates the potential for a new phase in the evolution of technology-enhanced learning (TEL). Chan et al. (2006) posit:

“... (The evolution) is characterized by 'seamless learning spaces' and marked by continuity of the learning experience across different scenarios or contexts, and emerging from the availability of one device or more per student. By enabling learners to learn whenever they are curious and seamlessly switch between different contexts, such as between formal and informal contexts and between individual and social learning, and by extending the social spaces in which learners interact with each other, these developments, supported by theories of social learning, situated learning, and knowledge-building, will influence the nature, the process and the outcomes of learning." 
Thus seamless learning could simply be characterized as "seamless flow of learning across contexts." The basic rationale is that it is not feasible to equip students with all the skills and knowledge they need for lifelong learning solely through formal learning. Henceforth, student learning should move beyond the acquisition of content knowledge to develop the capacity to learn seamlessly (W. Chen, Seow, So, Toh, \& Looi, 2010). Leung and Chan (2003), however, argue that mobile learning should become a part of the learning culture than an adjunct to it. We believe that genuine mobile-assisted seamless learning could not be taken for granted simply by assigning each learner a mobile device or by designing and enacting one-off mobile learning activities in which the designed learning processes do not go beyond the planned learning hours and venues. Learners need to be engaged in an enculturation process to transform their existing epistemological beliefs, attitudes, and methods of learning. Therefore, at the early stage of learners' engagement in mobile devices, teachers need to model the seamless learning process by gradually and systematically incorporating mobile learning activities into the formal curriculum. In addition, teachers should encourage learners to extend their learning into the informal, out-of-school context by picking up incidentally learned knowledge, applying their knowledge in real-life, and relating back or questioning the knowledge that they learned in the formal curriculum (Wong, Chen, Looi, \& Zhang, 2010).

We advocate the marriage of WMUTE and seamless learning (mediated by $24 \times 7$ access of $1: 1$ setting) as mobile seamless learning or MSL in short (to distinguish it from Kuh's (1996) more general notion of seamless learning). Subsequent literature on WMUTE learning cite different aspects of Chan et al. (2006), offer somewhat diversified and loose (re-)definitions of seamless learning (MSL in particular), and report on research studies with varied combinations of the features of MSL. Some carry a relatively techno-centric perspective that treats ubiquitous and context-aware technologies as the essential enablers of seamless learning without being interrupted while the learners switch locations or devices (e.g., Hwang, Tsai, \& Yang, 2008; Yu, Yang, \& Cheng, 2009).

Please cite:

Wong, L.-H., \& Looi, C.-K. (2011). What seams do we remove in mobile assisted seamless learning? A critical review of the literature. Computers \& Education, 57(4), 2364-2381. 
Some even treat seamless learning and ubiquitous learning as synonyms (e.g., $\mathrm{Ng} \&$ Nicholas, 2007; W. Wang \& Wang, 2008), which we do not concur. Ubiquitous learning is more about how ubiquitous technology supports the learners in the right way, in the right place, and at the right time, based on the personal and environmental contexts in the real world (Hwang, et al., 2008). Seamless learning, as defined and described by Kuh (1996) and Chan et al. (2006), is more a learner's habit of mind which may or may not need to be mediated or supported by technology. Other definitions in the literature place greater emphasis on students' habits of mind in personal and collaborative learning (e.g., Liu, 2008; Rogers \& Price, 2009), and the educational ecology to support seamless learning (e.g., Looi, et al., 2010). Specifically, Deng, Lin, Kunshuk and Chan (2006) characterize MSL scenarios into three dimensions:- locations, scales of number of co-learners, and learning activity (or pedagogical) models.

The diversity of MSL-related expositions and studies suggests that MSL is a multi-aspect, multi-dimensional learning model . The questions that come across our mind are: What are the salient features of MSL that the research community considers crucial in facilitating seamless learning? In the following section, we will narrate our systematic effort in unpacking the prior literature of MSL and reconstructing them into ten dimensions. Each of the dimensions will be further elaborated by discussing the relevant expositions and learning designs in the prior literature, and by presenting our summarized or rise-above views.

\section{An Analysis of MSL Literature}

\subsection{Analysis Methods}

With these questions in mind, we did an analysis of MSL-related literature published between 2006 and March 2011. Our literature scan started with rounds of searches on several e-databases including Google Scholar, ERIC, Web of Knowledge and British Education Index, with the combinations of search keywords ["seamless learning" AND ("mobile learning" OR "ubiquitous learning" OR "handhelds")], or "seamless mobile learning", and yielded a set of candidate papers. Please cite:

Wong, L.-H., \& Looi, C.-K. (2011). What seams do we remove in mobile assisted seamless learning? A critical review of the literature. Computers \& Education, 57(4), 2364-2381. 
Added to the initial set of papers were the papers that cited Chan et al. (2006) AND cited the term "seamless learning", which heavily overlap with the papers yielded with the above-mentioned keywords. We went through these candidate papers to identify those which directly provide or cite definitions/descriptions of the term "seamless learning", and/or those which report on WMUTE designs or studies that prominently incorporate some of the salient features of MSL identified by Chan et al. (2006).

As our main interest was to find out how the research community viewed the notion of seamless learning collectively, we decided to filter out papers which did not cite the term "seamless learning" - that is, the authors probably did not even consciously position their reported studies as instances of seamless learning albeit encompassing certain MSL features. Finally, we matched or grouped papers reporting on different aspects of the same study and treated each set of such papers as one paper in our subsequent analysis. We identified 54 papers (or sets of papers), including Chan et al. (2006), for the purpose. The selected papers could roughly be classified in Table 1 .

\section{Table 1: Selected papers for review}

\begin{tabular}{|c|c|}
\hline $\begin{array}{l}\text { Conceptual work on } 1: 1 \text { seamless or } \\
\text { ubiquitous learning }\end{array}$ & $\begin{array}{l}\text { Chan et al. (2006); Deng et al. (2006); Ng \& Nicholas (2007); Chiu, Kuo, } \\
\text { Huang \& Chen (2008); Hwang et al. (2008); So, Kim \& Looi (2008); W. } \\
\text { Wang \& Wang (2008); Kukulska-Hulme, Sharples, Milrad, } \\
\text { Arnedillo-Sánchez \& Vavoula (2009); Obisat \& Hattab (2009); Otero, Milrad, } \\
\text { Rogers, Santos, Veríssimo \& Torres (2011); Rogers \& Price (2009) }\end{array}$ \\
\hline $\begin{array}{l}\text { Development of technologies or } \\
\text { pedagogical designs to support } 1: 1 \\
\text { regular classroom-based learning }\end{array}$ & $\begin{array}{l}\text { Chan, Chen \& Chou (2006); S.-B. Chang, Ching \& Chen (2006); Li, Feng, } \\
\text { Zhou \& Shi (2009); Miyata, Sannomiya \& Suzuki (2010) }\end{array}$ \\
\hline $\begin{array}{l}\text { Development of technologies or } \\
\text { pedagogical strategies to support } \\
\text { one-off or short-term } 1: 1 \\
\text { context-aware ubiquitous learning }\end{array}$ & $\begin{array}{l}\text { Yang (2006); C.-S. Chang \& Chen (2007); Lee, Wu, Lee \& Hwang (2007); } \\
\text { Tan, Liu \& Chang (2007); Chen, Kinshuk, Wei \& Yang (2008); Milrad } \\
\text { (2008); Ogata et al. (2008); Rogers \& Price (2008); Sánchez \& Salinas } \\
\text { (2008); Spikol \& Milrad (2008); Wyeth et al. (2008); Bick \& Pawlowski } \\
\text { (2009); Chu, Lee \& Lu (2009); Seow, Zhang, Chen, Looi \& Tan (2009); } \\
\text { Sharples, Arnedillo-Sánchez, Milrad, \& Vavoula (2009); So, Seow \& Looi } \\
\text { (2009); W.-C. Shih \& Tseng (2009); Maldonado \& Pea (2010); J.-L. Shih, } \\
\text { Chu, Hwang, \& Kinshuk (2010) }\end{array}$ \\
\hline $\begin{array}{l}\text { Development of technologies or } \\
\text { pedagogical strategies to support } \\
\text { specific ongoing 1:1 learning activities }\end{array}$ & $\begin{array}{l}\text { H.-J. Huang (2007); Y.-T. Huang et al. (2007); Lin, Chen \& Chen (2008); } \\
\text { Metcalf, Milrad, Cheek, Raasch, \& Hamilton (2008); Pham-Nguyen \& } \\
\text { Garlatti (2008); Liao, Chou, \& Yang (2009); Uosaki, Li, Hou, Ogata \& Yano }\end{array}$ \\
\hline
\end{tabular}

Please cite:

Wong, L.-H., \& Looi, C.-K. (2011). What seams do we remove in mobile assisted seamless learning? A critical review of the literature. Computers \& Education, 57(4), 2364-2381. 


\begin{tabular}{|l|l|}
\hline & (2010); J. Wang \& Li (2008); Wong, Chin, Tan, \& Liu (2010) \\
\hline Longer term 1:1, 24x7 programs or & Chapel (2008); Kerawalla et al. (2007); Khan \& Zia (2007); Lai, Yang, Chen, \\
development of socio-technical & Ho \& Chan (2007); Vogel, Kennedy, Kuan, Kwok \& Lai (2007); Yu et al. \\
infrastructure that support such & (2009); Zhang \& Maesako (2009); Bentley et al. (2010); El-Bishouty, Ogata, \\
programs & Ayala \& Yano (2010); Looi et al. (2010); Zhao \& Okamoto (2011) \\
\hline
\end{tabular}

In analyzing each paper or set of papers, we looked at two aspects - (1) How seamless learning was explicitly defined or described in words? (2) What were the salient or potentially relevant MSL features being incorporated into the reported WMUTE designs? Some papers covered only one of these two aspects and were therefore not analyzed in the missing aspect. For instance, Chan et al. (2006) only defines seamless learning but does not propose or study a concrete WMUTE design, and therefore were only analyzed in aspect (1). Among the 54 selected papers, 13 of which were analyzed in aspect (1) only, 34 were analyzed in aspect (2) only, and 7 were analyzed in both aspects. We coded and tabulated the papers in terms of salient or potentially relevant MSL features, and combine similar features where necessary (see Appendix 1). The early round of coding was largely guided by the explicit definitions or descriptions of seamless learning given by the 20 papers analyzed in aspect (1). That is, the explicitly stated MSL features were compiled and became the preliminary set of codes that were used to code or re-code the 41 papers analyzed in aspect (2). Through constant comparison (Strauss \& Corbin, 1990), the coding scheme were progressively refined and eventually distilled into ten MSL features which will be described in the next section. It is important to note that it is not our intention to provide a definitive account of seamless learning or MSL through this exercise. Instead, our main interest is to induce and compile a set of MSL features that may inspire and inform future MSL designers in incorporating appropriate sets of features in their designs to maximize the learning effects.

\subsection{Identified MSL Features/Dimensions}

Through the above-stated analysis, we identified ten salient features that characterize the seamlessness of a WMUTE design:

Please cite:

Wong, L.-H., \& Looi, C.-K. (2011). What seams do we remove in mobile assisted seamless learning? A critical review of the literature. Computers \& Education, 57(4), 2364-2381. 
(MSL1) Encompassing formal and informal learning;

(MSL2) Encompassing personalized and social learning;

(MSL3) Across time;

(MSL4) Across locations;

(MSL5) Ubiquitous knowledge access (a combination of context-aware learning, augmented reality learning, and ubiquitous Internet access);

(MSL6) Encompassing physical and digital worlds;

(MSL7) Combined use of multiple device types (including "stable" technologies such as desktop computers, interactive whiteboards);

(MSL8) Seamless switching between multiple learning tasks (such as data collection + analysis + communication).

(MSL9) Knowledge synthesis (a combination of prior + new knowledge, multiple levels of thinking skills, and multi-disciplinary learning);

(MSL10) Encompassing multiple pedagogical or learning activity models.

We performed a "code and count" on the 54 selected papers (or paper sets) to derive the statistics of papers that cited or reported on the incorporations of individual features. The results are presented in Table 2.

Table 2: Statistics of the citations or incorporations of individual MSL features by the reviewed papers

\begin{tabular}{|c|c|c|c|c|c|c|c|c|c|c|}
\hline & MSL1 & MSL2 & MSL3 & MSL4 & MSL5 & MSL6 & MSL7 & MSL8 & MSL9 & MSL10 \\
\hline $\begin{array}{l}\text { Number of papers } \\
\text { who cited the feature } \\
\text { in their definitions or } \\
\text { descriptions of MSL }\end{array}$ & 14 & 16 & 17 & 19 & 12 & 14 & 4 & 2 & 3 & 2 \\
\hline $\begin{array}{l}\text { Number of papers } \\
\text { who reported the } \\
\text { incorporation of the }\end{array}$ & 27 & 34 & 31 & 35 & 32 & 33 & 16 & 14 & 14 & 18 \\
\hline
\end{tabular}

Please cite:

Wong, L.-H., \& Looi, C.-K. (2011). What seams do we remove in mobile assisted seamless learning? A critical review of the literature. Computers \& Education, 57(4), 2364-2381. 


\begin{tabular}{lllllllllll}
\hline Total & 41 & 50 & 48 & 54 & 44 & 47 & 20 & 16 & 17 & 20 \\
\hline
\end{tabular}

We are cognizant that no explicit addressing of certain features in a given reviewed paper does not mean that these features were definitely absent from the authors' views on MSL or their WMUTE designs - for example, a simple description of seamless learning as "seamlessly switching between contexts" could implicitly refer to several features. Therefore, the statistics are meant to give us a sense of how the research community prioritizes the MSL features in their studies.

From Table 2, it is clear that MSL1-MSL6 have been more well-addressed, though MSL1, supposedly the essence of the "original" seamless learning as defined by Kuh (1996), is the least addressed one among the top 6 features. In fact, none of the 54 reviewed papers cited Kuh's (1996) definition of seamless learning. Nevertheless, it is the WMUTE research community who has enriched the "original" seamless learning model.

From further analysis on the concrete MSL system or learning designs reported in 39 out of the 54 papers (which we refer to as "reviewed MSL design papers" in the subsequent text), we discovered that each study encompasses a specific combination of the MSL features to varied extents. For example, one-off field trip designs (e.g., Milrad, 2008; Sharples, et al., 2009) tend to encompass MSL4, MSL5, MSL6 and MSL8 but not necessarily the rest. Longer term 1:1, 24x7 access programs or learning activities (e.g., Looi, et al., 2010; Metcalf, et al., 2008; Vogel, et al., 2007; Wong, Chin, et al., 2010) are more likely to incorporate MSL1-MSL6 and MSL9. Among the studies that incorporate the same feature, there might be different extents or "weights" of emphases between the two extremes of the spectrum. For example, for those who incorporate MSL1, Huang (2007) was more informal learning-inclined while Zhang and Maesako (2009) put greater emphasis on formal learning. In this regard, we re-position the 10 identified MSL features as 10 MSL dimensions. In the next few sections, we provide a detailed discussion of the 10 MSL dimensions.

\section{(MSL1) Encompassing formal and informal learning}

Please cite:

Wong, L.-H., \& Looi, C.-K. (2011). What seams do we remove in mobile assisted seamless learning? A critical review of the literature. Computers \& Education, 57(4), 2364-2381. 
Bridging the sharp boundary between formal and informal learning, as elaborated by Chan et al. (2006), is "to extend formal learning time, usually limited to the classroom, into informal learning time, to embrace opportunities for out-of-school learning driven by the personal interests of students" (p.6). However, we observe that there are discrepancies in the ways formal and informal learning are distinguished among the reviewed papers (and educational research literature in general). Some literature look exclusively at the physical context - learning that occurs out of the classroom or school compound, including teacher-planned field trips, are considered informal learning (e.g., Spikol \& Milrad, 2008; Wyeth, et al., 2008). For clarity, some papers adopt the terms "formal learning setting" and "informal learning setting" to mark the stated distinction (Vavoula \& Sharples, 2009). Other literature look into who is in control of the learning goals and content - only student-initiated learning or incidental (unintended) learning is regarded as informal learning (Looi, et al., 2010), while teacher-planned field trips could be characterized as "formal learning in informal settings" (as noted in the table in Appendix 1). Mann and Reimann (2007) refer to the two types of informal learning as "non-curriculum-oriented informal learning" and "curriculum-oriented informal learning" respectively.

Kukulska-Hulme et al. (2009) categorize four types of learning by two dimensions (externally or internally initiated; externally or internally structured): formal learning (externally initiated and structured), resource-based learning (externally initiated but internally structured), voluntary learning (internally initiated but externally structured), and informal learning (internally initiated and structured). So, Kim and Looi (2008) even classify students' "unintended learning (i.e., unplanned teachable moments; serendipitous learning) in class" as a special form of informal learning, which could be considered as "informal learning in formal settings".

In reviewing the reported MSL designs, we would also like to further distinguish "formal learning in informal settings" into two sub-types: (1) Teacher-led outdoor learning activities where students learn in groups, most likely within a confined time period (e.g., Kurti, Spikol, \& Milrad, 2008; J.-L. Shih, et al., 2010); (2) Students to carry out teacher-instructed learning activities beyond the formal class hours and/or teacher-led outdoor learning activities at their own convenience, such Please cite:

Wong, L.-H., \& Looi, C.-K. (2011). What seams do we remove in mobile assisted seamless learning? A critical review of the literature. Computers \& Education, 57(4), 2364-2381. 
as online discussions (e.g., H.-J. Huang, 2007), ongoing game playing (e.g., Metcalf, et al., 2008), or data collection or artifact creation (largely incidental encounters or improvisations) in daily life (most likely within 1:1, 24x7 access programs, e.g., Wong \& Looi, 2010). The two sub-types could be loosely characterized with the dimensions proposed by Kukulska-Hulme et al. (2009) where sub-type (1) and (2) fall into the "externally initiated and structured" and "externally initiated but (semi-)internally structured" categories respectively. We will further elaborate this point in the sub-section “(MSL3) Across time and (MSL4) Across locations.”

Finally, albeit a paper in e-learning context, Chen, Millard and Wills (2008) rise above the discrepancies and propose a four-dimensional model to characterize formal and informal learning, namely, learning objective, learning environment, learning activity and learning tools (and for each dimension an e-learning system is either student-led, teacher-led or negotiated).

From a pragmatic point of view, however, distinguishing which parts of a MSL design are formal learning components and which parts are informal learning ones is probably more for academic interest. Studies or practice of intertwining of both learning modes in recent years, most likely mediated by the technology, have been making them more and more indistinguishable. It is more important to employ the right learning activity models to address the right learning objectives. Therefore, in generating the table in Appendix 1 and the statistics in Table 2, we do not discriminate either way of distinguishing formal and informal learning. Sharples, Taylor and Vavoula's (2007) exposition may offer a perfect summary for this dimension,

"Instead of seeing mobile communication and online communities as a threat to formal education, we need to explore how learning can be transformed for the mobile age, through a dialogue between two worlds of education: one in which knowledge is given authority through the curriculum, the other in which it emerges through negotiation and a process of coming to mutual agreement.” (p.241)

\section{(MSL2) Encompassing personalized and social learning}

Please cite:

Wong, L.-H., \& Looi, C.-K. (2011). What seams do we remove in mobile assisted seamless learning? A critical review of the literature. Computers \& Education, 57(4), 2364-2381. 
Various forms of social learning were reported by the reviewed MSL design papers, ranging from face-to-face, in-situ strategies such as small-group collaborative tasks (e.g., Kurti, et al., 2008; Rogers \& Price, 2008), ad-hoc networked group forming (N.-S. Chen, et al., 2008), co-creation of student artifacts (e.g., Wong \& Looi, 2010; Wyeth, et al., 2008) and collaborative annotations (W.-C. Shih \& Tseng, 2009), to online strategies such as ad-hoc instructor or peer help seeking (e.g., Bick \& Pawlowski, 2009; El-Bishouty, et al., 2010; Lin, et al., 2008), synchronous group discussions (Yang, 2006), knowledge or student artifact sharing and peer reviews (Miyata, et al., 2010), and asynchronous peer discussions (H.-J. Huang, 2007). Most of the social learning forms are mediated by mobile devices but there are also some designs that make use of the technology or the WMUTE activity design to be a catalyst for face-to-face interactions, such as some $1: 1,24 \times 7$ programs (e.g., W. Chen, et al., 2010; Kerawalla, et al., 2007) that engage parents with their children's learning through or over the mobile devices that they bring home from school, or facilitation of face-to-face interactions with the community (Ogata, et al., 2008). Hybrid communication modes (both "through" and "over" the devices) occur in some of the field trip activities (e.g., Maldonado \& Pea, 2010).

Whereas Rogers and Price (2009) call for constraining the learning activity design so that students do not work largely by themselves but require some collaboration, Chan, Chen and Chou (2006) advocate a balance between personalized and social learning. They argue: "We researchers should be particularly sober in this era of intensive network communication where almost every researcher overemphasizes the importance of social exchanges in learning to the extent that we might have forgotten individual needs and affects." (p.15) However, despite citing "bridging personalized and social learning" as a salient feature of seamless learning in general, most of the reviewed MSL design papers tend to discuss or analyze personalized and social learning in their studies separately or only focus on one aspect. Very few papers did discuss the mechanism of bridging the two in their MSL designs (e.g., Wong, Chin, et al., 2010; H. Zhang \& Maesako, 2009).

(MSL3) Across time and (MSL4) Across locations

Please cite:

Wong, L.-H., \& Looi, C.-K. (2011). What seams do we remove in mobile assisted seamless learning? A critical review of the literature. Computers \& Education, 57(4), 2364-2381. 
From e-learning to WMUTE, the most publicly known phrase to describe these new advancements in learning technology is no doubt "learning anytime, anywhere." WMUTE enhances student learning whenever and wherever they are curious and be motivated to learn (Chan, Roschelle, et al., 2006; Lin, et al., 2008). This is particularly true for longer term 1:1, 24x7 programs, though external factors such as parental interference might reduce the students' access to their assigned mobile devices. One particular example was reported by Wong, Chin, Tan, \& Liu (2010), where some parents, out of fear of losing or damaging the mobile devices, forbad their 10-year-old children who participated in the study to bring their loaned smartphones out of their homes except for bringing them to the school.

Recognizing that many of the reviewed MSL designs were not intended to offer 1:1, 24x7 but one-off activity or digital classroom solutions, we loosened the "criteria" of the two dimensions by positioning them as "across time" (MSL3) and "across locations" (MSL4) respectively. In our analysis on the MSL design papers for generating the table in Appendix 1, we consider one-off activity designs which are limited to a relatively short period (e.g., less than three hours - this is an arbitrary threshold and therefore only serves as a guideline), such as within a classroom session or a field trip, not conforming to MSL3 (W.-C. Shih \& Tseng, 2009; e.g., Spikol \& Milrad, 2008). Similarly, one-off activity designs which confine the learners to single, relatively small areas are considered not conforming to MSL4, e.g., activities within physical classrooms (e.g., Miyata, et al., 2010) or elementary school compounds (e.g., J.-L. Shih, et al., 2010). The point that we are trying to make here, without any judgmental intention, is that this set of MSL designs did not or not fully exploit the WMUTE affordances of learning anytime and/or anywhere - but such design decisions were made probably due to the one-off nature of the activities and/or the limitation of resources such as the availability of mobile devices. Context-aware learning activities, such as those which leverage on RFID or QR-code tags for the learners' context-aware information access (e.g., J.-L. Shih, et al., 2010; Tan, et al., 2007), would even need to take place within predefined areas (Hwang, et al., 2008).

As we adopted full activity design, rather than when mobile devices are used, as the unit of analysis, we classified the designs that adopted the learning flow of classroom (theories and Please cite:

Wong, L.-H., \& Looi, C.-K. (2011). What seams do we remove in mobile assisted seamless learning? A critical review of the literature. Computers \& Education, 57(4), 2364-2381. 
preparation) - site - classroom (learning consolidation) (see the exposition by Pintus, Carboni, Paddeu, Piras, \& Sanna, 2004) as those conforming to MSL4 (e.g., Ogata, et al., 2008; Seow, et al., 2009; Sharples, et al., 2009). This is consistent with the argument of some literature that seamless learning or 1:1 WMUTE is intended to bridge indoor and outdoor learning activities (e.g., Lin, et al., 2008; Maldonado \& Pea, 2010; Milrad, 2008).

More ambitious attempts in increasing the seamlessness of the students' learning experience were to extend the supposedly one-off activity designs into ongoing, "cross-time and cross-location" socio-constructivist learning (i.e., the sub-type (2) of "formal learning in informal settings" as we discussed before). Three such studies were "Chinatown 2.0" (So, et al., 2009), "Move, Idioms!" (Wong, Chin, et al., 2010) and the Water Quality Unit under LET'S GO! Project (Maldonado \& Pea, 2010).

The first two studies were intended to address the potential pitfall of one-off activities where students were provided with the opportunity to interact with the environment but were not subsequently supported in deepening their understanding through textual knowledge (Pea \& Maldonado, 2006). In both studies, apart from in-class, face-to-face consolidations of the learning gains after the outdoor activities, students were given additional weeks to discuss on asynchronous forums about their learning experiences and artifacts created, which can be characterized as how So, et al. (2009) put it, "artifacts as a mediating tool for knowledge building (co-construction)" (p.370). For "Move, Idioms!" which is a 1:1, 24x7 learning design, the artifact generation carried on in students' after-school day-to-day life, thereby continuously enriched the artifact repository as valuable resources for seamless (prior and new, abstract and concrete) knowledge co-construction (Wong, Chen, Zhan, \& Chin, in-press). The limited accessibility (for "Chinatown 2.0" where students needed to return the devices to the school right after the field trip) or the technical constraint (for "Move, Idioms!" where the wiki space for artifact sharing, revisions and peer reviews were not editable through the smartphones) of the mobile devices were compensated by the use of Web 2.0 technology and home desktops.

The third study brought the students to a creek to measure the water quality (Maldonado \& Pea, 2010). Geotagging data, including the students' hypotheses and reasoning, allowed them to Please cite:

Wong, L.-H., \& Looi, C.-K. (2011). What seams do we remove in mobile assisted seamless learning? A critical review of the literature. Computers \& Education, 57(4), 2364-2381. 
conduct longer term research, sampling conditions in the same location during different seasons, as well as compare measurements taken in different areas of the creek, thus achieving both the "cross-time" and "cross-location" features. We believe these three typical extending-one-off-to-ongoing learning designs have the potential to be distilled and become a design-based research model for MSL, and WMUTE in general, where research studies are still currently largely conformed to one-off activity designs.

(MSL5) Ubiquitous knowledge access

MSL5 and MSL6 may come hand-in-hand but we decided to separate them into two overlapping dimensions in order to underline their differences - that is, MSL5 is about pulling or pushing of information from the Internet when learning is taking place, while MSL6 is about the complete learning experience or habit that encompasses the physical and digital worlds (which will be elaborated in the next sub-section). Specifically, we included "context-aware learning" and “ubiquitous Internet information access" into MSL5.

In most of the reviewed papers that carry a techno-centric view on MSL, context-aware technology has been the killer feature for MSL or ubiquitous learning. Just-in-time, contextualized information supplied by the technology can serve as evidence to support partially-formed ideas and misunderstandings, to trigger comparison with previously stored data on the device, as well as to support an inquiry process or dialogue in-situ (Rogers, et al., 2007). Such context-aware learning may again come in different forms - and many of which may go beyond information supply by providing other types of learning support. There are location-aware learning systems where students tap on GPS, RFID or QR-code tags to push or pull information corresponding to specific locations (e.g., Rogers \& Price, 2008; J.-L. Shih, et al., 2010), and/or employ virtual maps for site navigation (e.g., Ogata, et al., 2008; Spikol \& Milrad, 2008). There are also context-aware learning systems that make use of sensors to detect environmental/physical contexts such as temperature and offer contextualized learning support (Hou, Ogata, Miyata, Li, \& Liu, 2010). Leveraging on Artificial Intelligence, in particular Ambient Intelligence (ISTAG - IST Advisory Group, 2003), certain Please cite:

Wong, L.-H., \& Looi, C.-K. (2011). What seams do we remove in mobile assisted seamless learning? A critical review of the literature. Computers \& Education, 57(4), 2364-2381. 
systems may even provide more personalized support by taking into account all the above contextual information as well as the learner profile (e.g., Yang, 2006; Zhao \& Okamoto, 2011). Some studies (e.g., Maldonado \& Pea, 2010; So, et al., 2009) moved beyond "consumption" of contextual information by augmenting physical spaces with peer-to-peer information exchanges and further discussions, and by using geospatial mappings between the mobile device and the physical world. Hwang et al. (2008) gave a comprehensive summary of such MSL applications under the term "context-aware u-learning".

On the contrary, ubiquitous (i.e., anytime, anywhere) non-context-aware Internet information retrieval may be seen by many as a typical mobile device functionality that is not worthy to be one of the MSL dimensions (or part of it). However, we included some of the reviewed MSL design papers who consider the stated affordance as one of the salient features of their seamless learning solutions. Such examples include a mobile forum "StudentPartner" (H.-J. Huang, 2007), a PDA-based online video query and retrieval system (Y.-T. Huang, et al., 2007), a mobile learning resource portal (J. Wang \& Li, 2008), and certain 1:1, 24x7 programs (e.g., Kerawalla, et al., 2007; Looi, et al., 2010; Vogel, et al., 2007) that enable students to access to the Internet anytime, anywhere.

\section{(MSL6) Encompassing physical and digital worlds}

Chan et al. (2006) elaborate this dimension in a techno-centric fashion which could probably be attributed to MSL5 instead, "Combining digital and physical worlds with sensors, smart rooms, and ambient environments that capture real-world information of users, devices, and locations (geographical information systems) and represent it in a format that is usable in the digital realm." (p.8) In addition, the authors proposed the following research question for 1:1 TEL studies, which sounded more like a warning on the potential downside of this dimension, "How can learning productively leverage both the virtual world and the physical world at the same time, especially when absorption in one medium interferes with metacognitive awareness or when attention switching might contribute to cognitive overload?" (p.12)

In contrast, we are looking at this dimension more in the context of students' learning experience, as stated before. Whereas the rise of e-learning and web-based learning a decade ago

Please cite:

Wong, L.-H., \& Looi, C.-K. (2011). What seams do we remove in mobile assisted seamless learning? A critical review of the literature. Computers \& Education, 57(4), 2364-2381. 
had resulted in educators' concern of aggravating the digital natives' indulgence in the cyberspace, we argue that through proper MSL design that emphasizes learners' sensemaking and interactions with the reality (e.g., Ogata, et al., 2008; Rogers \& Price, 2008; Wong, Chin, et al., 2010), the WMUTE technology would instead serve as a stimulus to bring them "back" to the physical world, thus striking a balance between their "presences" in both the physical and digital worlds.

Specific examples of such learning experience could be found in two of the studies we elaborated under MSL3 and MSL4 (So, et al., 2009; Wong, Chin, et al., 2010) where students made use of Web 2.0 technology in an ongoing basis to discuss and co-construct knowledge on the artifacts created with their devices as well as their learning experience during the field trip or in their daily life. For some 1:1, 24x7 programs (e.g., Kerawalla, et al., 2007; Looi, et al., 2010), out-of-school self-directed learning with the aid of mobile devices were encouraged. The potential effect is that the use of the mobile device become a routine practice and is assimilated to everyday life experiences. Rapid connections could be made between ideas and observations in the physical world (W. Chen, et al., 2010) which are transformed into digital forms for subsequent processing and sharing.

As shown in Appendix 1, not all MSL designs with "ubiquitous knowledge access" (i.e., having MSL5) are attributed as having MSL6 as well. We consider those MSL designs, which retrieve contextualized or other online information only for "consumption" purpose but with no other learning activity taking place in the digital space, as designs that do not encompass physical and digital worlds, as are other designs whose learning activities only take place in the digital world (e.g., Y.-T. Huang, et al., 2007; Metcalf, et al., 2008; J. Wang \& Li, 2008).

\section{(MSL7) Combined use of multiple device types}

The notion of 1:1, according to Cathie Norris and Elliot Soloway (2002, 2004), is in fact "one device or more per student." However, there is a variety of models on the combined use of multiple device types as described or employed in the reviewed papers. Wang and Li (2008), for example, focused on constructing a mobile learning platform where learners can retrieve the same learning resources with different types of devices. Chang and Chen (2007) designed an integrated environment for learners "to connect with heterogeneous systems, diverse instructional platforms, for heterogeneous devices." Hwang et al. (2008) describe seamless learning feature in ubiquitous learning environments that "learning services will not be interrupted even though the learner is Please cite:

Wong, L.-H., \& Looi, C.-K. (2011). What seams do we remove in mobile assisted seamless learning? A critical review of the literature. Computers \& Education, 57(4), 2364-2381. 
moving from place to place and the environment (including the learning devices and networks) is changing."

Other studies seek for mixed usage of mobile and stable technologies. Wong (2010b) (cited in: Looi, Wong, \& Song, in-press), for instance, advocates a 'division of labor' strategy, with each student keeping one handheld device (such as smart-phone or PDA) and one netbook or laptop at hand, $24 \times 7$, to handle the needs of various formal and informal, planned and incidental learning tasks. Ng and Nicholas (2007), argue that "at least in the mainstream school education context, seamless learning requires planned interactions between mobile and stable technologies." (p.189) Similarly, Zhao \& Okamoto (2011) developed a technical solution with the clear aim of bridging the gap between mobile and desktop computing for learning purposes. Other studies that couple mobile devices (usually for formal classes or field trips) and desktop computers (usually for after-school learning activities) include system development works such as (Lai, et al., 2007; Yang, 2006), or learning activity designs such as (Lin, et al., 2008; Maldonado \& Pea, 2010; So, et al., 2009), again for addressing the present limitation of after-school accessibility of mobile devices for most of the schools and students.

Certain outdoor learning activity designs involve "synchronous" use of multiple device types. In the second trial reported by Kurti et al. (2008), students broke into outdoor group and indoor group. The outdoor students used smartphones to collect data and transmitted to the indoor students, who subsequently search for relevant information online with a laptop. More complex field trip activity such as The Ambient Wood activities (Rogers \& Price, 2008) required each student group to seamlessly switch between the use of a PDA, a probing tool and a walkie-talkie during their inquiry activity in a woodland. Of course, the latest smartphone models may offer an all-in-one solution (perhaps with additional plug-in accessories) to eradicate the need of carrying multiple devices around - but the new challenge is that could individual students seamlessly switch between multiple smartphone applications to carry out multiple learning tasks? This issue is related to MSL8 which we will elaborate later.

With the proliferation of netbook as a viable laptop replacement, for 1:1, 24x7 MSL access, we advocate each student to keep one smartphone and one netbook or notebook device at hand to Please cite:

Wong, L.-H., \& Looi, C.-K. (2011). What seams do we remove in mobile assisted seamless learning? A critical review of the literature. Computers \& Education, 57(4), 2364-2381. 
handle the needs of various formal and informal, planned and incidental learning tasks. The small size and light weight of smartphones, which can be turned on and off instantaneously, make them the perfect tool for students to perform quick and rapid learning tasks on the move, such as photo taking, audio and video recording, note taking, Internet information retrieval, data exchange and communication, map navigation and geotagging, and so on. Whenever the students have the chance to sit down (either during a field trip, on the public transport, in the library, in the park, or at home), their Netbooks or notebook devices would compensate the limitation of computing power and screen size of the smartphones by supporting them in carrying out more "complex" learning tasks such as detailed data analysis, report writing, Powerpoint creation, learning in 3D virtual environments, etc. We foresee the division of labor between the two devices would bring the students a more holistic, seamless learning experience by enabling or supporting them to engage in a greater range of learning activities, which is what $24 \times 7$ access of either device could not achieve.

Dillenbourg (2010) talks about the range of uses depending on the computer-student ratio ranging from the use of multiple computing devices (like sensors) by 1 student (10:1) to a class of students to 1 interactive whiteboard (1:all), including the in-between usage scenarios of 1:1 (as in the initial notions of MSL), 1:2 (as in pair work sharing a device), and 1:4 (as in small group work discussed mediated by a shared device. Clear, each of these computer-student ratios provide different dynamics of interaction and collaboration that support a myriad of learning designs. From the learner's point of view, the individual herself is the invariant and there needs to be a sense of seamlessness in switching contexts between these different designs.

(MSL8) Seamless switching between multiple learning tasks

Extending from the exposition of MSL7, this dimension is about seamless and perhaps rapid switches between multiple learning tasks on the move (e.g., during field trips), mediated by the device. As Rogers, Connelly, Hazlewood and Tedesco (2010) state,

Please cite:

Wong, L.-H., \& Looi, C.-K. (2011). What seams do we remove in mobile assisted seamless learning? A critical review of the literature. Computers \& Education, 57(4), 2364-2381. 
"Compared with the learning that takes place when using a tethered PC in a classroom, where individual or pairs of student's attention is primarily focused on what is happening at the computer screen, mobile computing devices tend to be used for short bursts of times (e.g., entering and comparing data, looking up and reviewing information, sending texts or photos to remote people) to support foregrounded physical activities (e.g., observing, probing, measuring) in a particular environment (e.g., city centre, forest). A potential benefit of being able to switch intermittently between activities and foci of interest ... is to provide multiple opportunities for students to step in and out and reflect upon these transitions. In so doing, it could deepen their understanding and help integrate their ideas, data and observations." (p.112)

Therefore, albeit not a well-cited dimension of seamless learning in general among the reviewed MSL papers (only remotely posited by So et al. (2008)), we deem it as another important mobile affordance to be incorporated into the MSL dimensions for our analysis. Our interest is to encourage MSL system developers and outdoor learning designers to move beyond overemphasis on context-aware information retrieval, plus relatively straightforward or structured learning activities (e.g., Khan \& Zia, 2007; J.-L. Shih, et al., 2010; Yang, 2006), by integrating a variety of personal and group inquiry tasks into the learning flows (e.g., Maldonado \& Pea, 2010; Rogers \& Price, 2008; Spikol \& Milrad, 2008). Some designs strike a balance between the two by restricting in-situ activities to, for example, data collection and measurement, quick brainstorming or Internet search, brief note taking and geotagging (i.e., preliminary meaning making), etc., and save the more sophisticated data analysis and knowledge co-construction tasks (i.e., deep meaning making) for the follow-up learning community after the field trips (e.g., So, et al., 2009; Wong, Chin, et al., 2010). The embodiment of such inquiry tasks in MSL learning flows could serve as a means to nurture the $21^{\text {st }}$ century skills and competencies.

\section{(MSL9) Knowledge synthesis}

Please cite:

Wong, L.-H., \& Looi, C.-K. (2011). What seams do we remove in mobile assisted seamless learning? A critical review of the literature. Computers \& Education, 57(4), 2364-2381. 
Apart from nurturing self-directed learners, the ultimate aim of embracing seamless learning is arguably the synthesis of knowledge, and the acquiring of the skills to perform the synthesis. To a student, what is the significance of "seamless switching between different learning contexts"? It is for the sake of acquiring data and knowledge in different domains and forms, and recording, organizing, processing and reflecting upon the knowledge. This is mediated by her own mobile device that serves as a learning hub, thereby making connections and perhaps identifying discrepancies between pieces of knowledge and ultimately, knowledge construction. However, same as MSL8, this dimension is rarely attributed as one of the salient features of seamless learning. For example, $\mathrm{Ng}$ and Nicholas (2007) posit that tangible-mediated learning could allow for learners to combine and re-combine familiar knowledge in new, unfamiliar ways, thereby promoting creativity and higher order thinking. Similarly, So et al. (2008) advocate "mobile devices to be used in diverse subject areas for integrated curricula" as one of the considerations for the design of MSL activities. They argue that such experiences would provide a balance between abstract and concrete knowledge and lead to increase learner interest and motivation, and cohesive knowledge schema.

In our analysis, we included three potentially overlapping forms of knowledge synthesis into MSL9, namely, prior and new knowledge, multiple levels or stages of thinking skills, and multi-disciplinary learning. Many of the outdoor MSL activity designs and 1:1, 24x7 programs provide tasks which shifts the students' exercise of their thinking skills from lower-order to higher-order based on various taxonomies of thinking skills (Bloom, 1956; Crone-Todd, Pear, \& Read, 2000; Pear, Crone-Todd, Wirth, \& Simister, 2000). The tasks are designed for students to move up in complexity of the cognitive and thinking processes required (Commons, Trudeau, Stein, Richards, \& Krause, 1998), and scaffolding through and over the mobile technologies are provided to assist the students to move through the phases of knowledge, comprehension, abstraction, application, analysis, synthesis and evaluation of the current educational encounter. While Bloom's taxonomy would have the progression move from concrete to abstract skills, the seamless dimension of knowledge synthesis provides the richer interplay and intermingling of thinking with concrete levels of thinking with abstract levels of thinking.

Please cite:

Wong, L.-H., \& Looi, C.-K. (2011). What seams do we remove in mobile assisted seamless learning? A critical review of the literature. Computers \& Education, 57(4), 2364-2381. 
In generating the table in Appendix A, we only identified the reviewed MSL design papers which explicitly discussed the incorporation of any form of knowledge synthesis in their design consideration as those conforming to MSL9. There were designs which required the applications of cross-subject knowledge (e.g., Kurti, et al., 2008; Metcalf, et al., 2008), and emphasized the synthesis of prior and new knowledge (e.g., Lai, et al., 2007; Wong, Chin, et al., 2010) and/or the progression of thinking skills from concrete to abstract or vice-versa (e.g., Rogers \& Price, 2008; So, et al., 2009). Specifically, Yang (2006) developed a context-aware solution which has the potential to stimulate individual students in synthesizing prior and new knowledge. A student's past contexts as detected by her mobile device during her previous learning activities are stored in her "historical execution path" for the system to derive her learning profile and preferences. This piece of information is important for the system to deliver more personalized learning content and services when the student resumes learning under a new context.

(MSL10) Encompassing multiple pedagogical or learning activity models

Chang and Chen (2007) recommend the deployment of different learning models such as self-regulated learning, collaborative learning or activity learning for catering to the diversity of learning experiences. Therefore, one of their aims in developing a ubiquitous learning grid is to offer a tool which could support students and teachers in seamlessly switching between various learning models. Shih and Tseng (2009) have intended to address such a similar issue in the learning material retrieval system that they constructed. Apart from technological solutions, we are interested in how multiple pedagogical or learning activity models could be incorporated into a MSL activity design and be seamlessly stitched together in the learning flow. In the analysis of the reviewed MSL design papers, there is some ambiguity in judging whether individual designs are conformed to MSL10. For instance, should in-class didactic, instructivist theory learning prior to field trips (e.g., in Seow, et al., 2009) be counted as one pedagogical model in our analysis? Could we decompose a collaborative quiz answering activity during a field trip (e.g., in Sánchez \& Salinas,

Please cite:

Wong, L.-H., \& Looi, C.-K. (2011). What seams do we remove in mobile assisted seamless learning? A critical review of the literature. Computers \& Education, 57(4), 2364-2381. 
2008) into three different learning models, namely, collaborative learning, quiz, and authentic learning, and consider this single activity encompassing multiple learning models?

The learning point for the inclusion of this dimension is more about how WMUTE could be designed to facilitate or support a greater diversity of learning modes as compared with traditional learning. Obisat and Hattab (2009) move one step further by proposing the integration of personalized assessment with learning to become "one seamless learning activity". It is important, however, to note that an excessively complex learning flow may result in cognitive overload, as Rogers and Price (2008) observed in their Ambient Wood study, "the students decided themselves how to manage their time and which activities to pursue, so as not to get overloaded or distracted."

\section{Discussion and Conclusion}

We have unpacked the notion of mobile-assisted seamless learning (MSL) by doing a literature review of all WMUTE articles related to this notion. In our analysis, we find it conceptually clear and useful to see MSL from a framework that encompasses ten somewhat distinct dimensions.

In turn, we believe that it would help if new MSL work can be situated in this dimensional space. We notice that the ten dimensions could be loosely divided into three higher level categories that represent the major element of MSL that is foregrounded, namely, the technology (essentially MSL5 - ubiquitous knowledge access, and MSL7 - multiple device types), the pedagogy focus (essentially MSL8 - multiple learning tasks, and MSL10 - multiple pedagogical models), and the learner focus (i.e., more relevant to personal habit of mind, even though such dimensions could be incorporated into teachers' MSL design to nurture such habits among the students; MSL1 - formal and informal learning, MSL2 - personalized and social learning, MSL3 - across time, MSL4 across locations, MSL6 - physical and digital worlds, and MSL9 - knowledge synthesis). In the notion of seamless learning, technology and pedagogy may play a dominant part in driving, guiding and preparing young learners' seamless learning practice in their earlier years. As the learners are

Please cite:

Wong, L.-H., \& Looi, C.-K. (2011). What seams do we remove in mobile assisted seamless learning? A critical review of the literature. Computers \& Education, 57(4), 2364-2381. 
assimilating new learning practices, explicit instructional and learning designs should gradually take a backseat for learner-centric, technology-supported self-directed learning to take eminence.

The framework also allows us to identify research or design gaps in MSL. From Table 2, it is obvious that the MSL research community has been emphasizing the first six dimensions in their expositions and actual learning designs, i.e., encompassing formal and informal learning, encompassing personalized and social learning, mediating learning across time, mediating learning across locations, providing ubiquitous knowledge access, and encompassing physical and digital worlds. Such a research trend shows the strong influence of Chan et al.'s (2006) definition or description of the seamless learning notion (see the indented text in Section 3). However, through our relevant exposition in the previous section, we argue that the last four relatively unexplored dimensions have their respective utility and importance in facilitating more holistic seamless learning experiences and achieving more profound and sustainable learning outcomes. Despite the advent of new devices providing different functionalities and lifestyle use such as different-screen-size devices, large shared displays and multi-touch large screens, we believe we need more research in the combined yet seamless use of multiple device types for different contexts. We also hope to see more research studies that place greater emphasis on addressing the dimensions of seamless switching between multiple learning tasks, knowledge synthesis, and encompassing multiple pedagogical or learning activity models. A practitioner interested in adopting a MSL design or doing a new design can use our analysis to situate the space where the constraints or parameters of his or her design problem lie, and look at relevant design and research-based evidence of other related MSL systems to refine her own design.

The identification and the exposition of the 10 MSL dimensions will pave way to our future work that we hope to contribute to both academics (i.e., the theorization of seamless learning) and practice. For the latter case, as we firmly believe that every learner can be nurtured in the belief in and the skills for seamless learning with the aid of WMUTE (according to the outcomes of longer-term MSL studies by, e.g., Wong, Chin, et al., 2010; B. H. Zhang, et al., 2010), we will seek to develop a facilitated seamless learning process framework (as advocated by Wong, 2010a) that aims to guide future researchers and practitioners in designing MSL learning processes to gradually Please cite:

Wong, L.-H., \& Looi, C.-K. (2011). What seams do we remove in mobile assisted seamless learning? A critical review of the literature. Computers \& Education, 57(4), 2364-2381. 
transform learners into genuine self-directed seamless learners. Whereas many educators may carry an anecdotal view that it is a tall order for younger learners (K-12, especially K-6) with limited cognitive and self-regulatory capabilities to practice seamless learning, we argue that it is the present instructivist- and transmissionist-dominated formal education system and the exam-driven mindset that has shaped the learners' epistemological belief and learning strategies that gear towards passive absorption of authoritative knowledge being taught in the classroom. Congruent with knowledge building researchers' call (e.g., Pelletier, Reeve, \& Hallewood, 2006; J. Zhang, Scardamalia, Lamon, Messina, \& Reeve, 2007) for exposing children to such socio-constructivist activities at even younger ages before they are conditioned to the fixation of such conceptions, we advocate the same for fostering young seamless learners.

Humans are intrinsic sense makers, looking to organize new information so as to find meanings, significance, or patterns in it (Schank, 1999), in order to make sense of the world and cope with new situations and problems. As a counterpoise to the view of learning as a form of "knowledge transfer" (in formal learning setting), researchers (e.g., Weick, 1995) argue for the active-sense-making nature of learning. When learners cannot make sense of new information, they will either create sense or meaning for the information or leave the information as incomprehensible "noise" (Larsen-Freeman, 2002). Learning deficiencies can therefore be characterized as a learner's lack of the habits of mind and the cognitive skills in creating a new sense for new information. An undesirable consequence of this is doing rote memorization for the sake of doing formal assessments. Apart from the formal curriculum covered in the school, any experience or encounter in a learner's daily life is a potential resource for her sense making (or learning). By advocating MSL, it is our intention to combine the technological resources (essentially MSL5 and MSL7) and pedagogical means (essentially MSL8 and MSL10) to "ignite" (scaffold, nurture, and support) our learners" "inner fire" of sense making or sense creation (relevant to MSL9). Such dispositions are stimulated by new information (either intentionally or incidentally) accessed or sensed anytime, anywhere (MSL3 and MSL4), and within any context (MSL1, MSL2, and MSL6), thus enabling the learners to experience genuinely holistic learning.

Please cite:

Wong, L.-H., \& Looi, C.-K. (2011). What seams do we remove in mobile assisted seamless learning? A critical review of the literature. Computers \& Education, 57(4), 2364-2381. 


\section{References:}

American College Personnel Association. (1994). The student learning imperative: Implications for student affairs. Washington, D.C.: Author.

Barbosa, D. N. F., \& Geyer, C. F. R. (2005). Pervasive personal pedagogical agent: mobile agent shall always be with a learner. Proceedings of the IADIS International Conference on Mobile Learning 2005 (pp. 281-285), Qawra, Malta.

Bell, S. J. (2000). Creating learning libraries in support of seamless learning cultures. College \& Undergraduate Libraries, 6(2), 45-58.

Bentley, Y., Shegunshi, A., \& Scannell, M. (2010). Evaluating the impact of distance learning support systems on the learning experience of MBA students in a global context. Electronic Journal of e-Learning, 8(2), 51-62.

Bick, M., \& Pawlowski, J. M. (2009). Applying context metadata in ambient knowledge and learning environments - A process-oriented perspective. Proceedings of the Conference on Professional Knowledge Management 2009 (pp. 552-561), Solothurn, Switzerland.

Bloom, B. S. (Ed.). (1956). Taxonomy of educational objectives, the classification of educational goals - Handbook I: Cognitive domain. New York: McKay.

Brodersen, C., Christensen, B. G., Grønbæk, K., Dindler, C., \& Sundararajah, B. (2005) . eBag: A ubiquitous web infrastructure for nomadic learning. Paper presented at the International Conference on World Wide Web 2005, Chiba, Japan.

Chan, T.-W., Chen, F.-C., \& Chou, C.-Y. (2006). Profile enhanced classroom learning. Proceedings of the IEEE International Workshop on Wireless, Mobile and Ubiquitous Technology in Education (pp. 3-6), Athens, Greece.

Chan, T.-W., Roschelle, J., Hsi, S., Kinshuk, Sharples, M., Brown, T., et al. (2006). One-to-one technology-enhanced learning: An opportunity for global research collaboration. Research and Practice in Technology-Enhanced Learning, 1(1), $3-29$.

Chang, C.-S., \& Chen, T.-S. (2007). Building self-knowledge for learners in ubiquitous learning grid. Paper presented at the Technology Enhanced Learning Conference 2007, Jhongli, Taiwan.

http://mail.nutn.edu.tw/ chents/papers/TELearn2007.pdf

Chang, S.-B., Ching, E., \& Chen, Y.-F. (2006). Designing One-to-One Activities with a Cognitive Conflict Resolution Strategy. Proceedings of the International Computer Symposium 2006 (pp. 1505-1509), Taipei, Taiwan.

Chapel, E. (2008). Mobile technology: the foundation for an engaged and secure campus community. Computing in Higher Education, 20, 15-23.

Chen, N.-S., Kinshuk, Wei, C.-W., \& Yang, S. J.H. (2008). Designing a self-contained group area network for ubiquitous learning. Educational Technology \& Society, $11(2), 16-26$.

Please cite:

Wong, L.-H., \& Looi, C.-K. (2011). What seams do we remove in mobile assisted seamless learning? A critical review of the literature. Computers \& Education, 57(4), 2364-2381. 
Chen, W.-P., Millard, D. E., \& Wills, G. B. (2008). A four dimensional model of formal and informal learning. Proceedings of the International Conference on Computers in Education (pp. 339-343), Taipei, Taiwan.

Chen, W., Seow, P., So, H.-J., Toh, Y., \& Looi, C.-K. (2010). Extending students' learning spaces: Technology-supported seamless learning. Proceedings of the International Conference on Learning Sciences 2010 (pp. 484-491), Chicago, USA.

Chiu, P.-S., Kuo, Y.-H., Huang, Y.-M., \& Chen, T.-S. (2008). The ubiquitous learning evaluation method based on meaningful learning. Proceedings of the International Conference on Computers in Education 2008 (pp. 257-264), Taipei, Taiwan.

Chu, K.-K., Lee, C.-I., \& Lu, P.-C. (2009). A study of the effect of pupils' learning achievement on project-based learning with context awareness technology. In E. Damiani, J. Jeong, R. J. Howlett \& L. C. Jain (Eds.), New Directions in Intelligent Interactive Multimedia System and Services (pp. 211-221).

Berlin/Heidelberg: Springer-Verlag.

Commons, M. L., Trudeau, E. J., Stein, S. A., Richards, F. A., \& Krause, S. R. (1998) . The existence of developmental stages as shown by the hierarchical complexity of tasks. Developmental Review, 8(3), 237-278.

Crone-Todd, D. E., Pear, J. J., \& Read, C. N. (2000). Operational definitions for higher-order thinking objectives at the post-secondary level. Academic Exchange Quarterly, 4(3), 99-106.

Deng, Y.-C., Lin, T., Kinshuk, \& Chan, T.-W. (2006). Component Exchange Community: A model of utilizing research components to foster international collaboration. Educational Technology \& Society, 9(3), 218-231.

El-Bishouty, M. M., Ogata, H., Ayala, G., \& Yano, Y. (2010). Context-aware support for self-directed ubiquitous-learning. Mobile Learning and Organisation, 4(3), $317-331$.

Hou, B., Ogata, H., Miyata, H., Li, M., \& Liu, Y. (2010). JAMIOLAS 3.0: Supporting Japanese mimicry and onomatopoeia learning using sensor data. Mobile and Blended Learning, 2(1), 40-54.

Huang, H.-J. (2007). A study on hybrid seamless collaborative learning environment with active push e-mail technology. Master Dissertation, National Central University, Jhongli, Taiwan.

Huang, Y.-T., Chung, C.-I., Tsai, C.-C., Shen, C.-H., Wu, Y.-C., \& Yang, J.-C. (2007) . A mobile video question answering system for e-learning. Proceedings of the IEEE International Conference on Advanced Learning Technologies 2007 (pp. 74-78), Niigata, Japan.

Hwang, G.-J., Tsai, C.-C., \& Yang, S. J.H. (2008). Criteria, strategies and research issues of context-aware ubiquitous learning. Educational Technology \& Society, $11(2), 81-91$.

ISTAG - IST Advisory Group. (2003). Ambient Intelligence: From Vision to Reality.

Please cite:

Wong, L.-H., \& Looi, C.-K. (2011). What seams do we remove in mobile assisted seamless learning? A critical review of the literature. Computers \& Education, 57(4), 2364-2381. 
Kazmer, M. (2005). Cats in the classroom: Online learning in hybrid space. First Monday, 10(9), Electronic journal, no pagination.

Kerawalla, L., O'Connor, J., Underwood, J., duBoulay, B., Holmberg, J., Luckin, R., et al. (2007). Exploring the potential of the homework system and Tablet PCs to support continuity of numeracy practices between home and primary school. Educational Media International, 44(4), 289-303.

Khan, M. T., \& Zia, K. (2007). Future context-aware pervasive learning environment: Smart Campus. Paper presented at the International Conference on Integration of Information Technology in Science Education 2007, Gazimagusa, Turkish Republic of Northern Cyprus. http://www.init.org.pk/PapersAndPublications/IntigrationofIT/Paper6.pdf

Kuh, G. D. (1996). Guiding principles for creating seamless learning environments for undergraduates. College Student Development, 37(2), 135-148.

Kukulska-Hulme, A., Sharples, M., Milrad, M., Arnedillo-Sánchez, I., \& Vavoula, G. (2009). Innovation in Mobile Learning: a European Perspective. Mobile and Blended Learning, $1(1), 13-35$.

Kurti, A., Spikol, D., \& Milrad, M. (2008). Bridging outdoors and indoors educational activities in schools with the support of mobile and positioning technologies. Mobile Learning and Organisation, 2(2), 166-186.

Lai, C.-H., Yang, J.-C., Chen, F.-C., Ho, C.-W., \& Chan, T.-W. (2007). Affordances of mobile technologies for experiential learning: the interplay of technology and pedagogical practices. Computer Assisted Learning, 23(4), 326-337.

Larsen-Freeman, D. (2002). Making sense of frequency. Studies in Second Language Acquisition, 24, 275-285.

Lee, S.-H., Wu, X., Lee, M.-H., \&Hwang, D.-H. (2007). Design of context ontology based on context-aware information for adaptive u-learning system. Proceedings of the International Conference on Applications and Principles of Information Science 2007 (pp. 145-148), Kuala Lumpur, Malaysia.

Leung, C.-H., \& Chan, Y.-Y. (2003). Mobile learning: A new paradigm in electronic learning. Proceedings of the IEEE International Conference on Advanced Learning Technologies 2003 (pp. 76-80), Athens, Greece.

Li, X., Feng, L., Zhou, L., \& Shi, Y. (2009). Learning in an Ambient Intelligent world: Enabling technologies and practices. IEEE Transactions on Knowledge and Data Engineering, 21(6), 910-924.

Liao, C.-J., Chou, C.-C., \& Yang, J.-T. D. (2009). The construction of an ontology-based ubiquitous learning grid. Distance Education Technologies, 7(3), $1-25$.

Lin, H.-Y., Chen, C.-Y., \& Chen, W.-C. (2008). Scaffolding m-Learning approach of automotive practice courses in senior vocational high school. Proceedings of the ASEE/IEEE Frontiers in Education Conference (pp. 112-117), Saratoga Springs, USA.

Please cite:

Wong, L.-H., \& Looi, C.-K. (2011). What seams do we remove in mobile assisted seamless learning? A critical review of the literature. Computers \& Education, 57(4), 2364-2381. 
Liu, C.-C. (2008). Beyond the ownership of handheld devices: active learning with ubiquitous learning minds. Proceedings of the IEEE International Conference on Wireless, Mobile, and Ubiquitous Technology in Education 2008 (pp. 11-19), Beijing, China.

Looi, C.-K., Seow, P., Zhang, B. H., So, H.-J., Chen, W., \& Wong, L.-H. (2010). Leveraging mobile technology for sustainable seamless learning: A research agenda. British Journal of Educational Technology, 42(1), 154-169.

Looi, C.-K., Wong, L.-H., So, H.-J., Seow, P., Toh, Y., Chen, W., et al. (2009). Anatomy of a mobilized lesson: Learning my way. Computers \& Education, 53(4), 1120-1132.

Looi, C.-K., Wong, L.-H., \& Song, Y. (in-press). Discovering Mobile Computer Supported Collaborative Learning. In C. Hmelo-Silver, A. O'Donnell, C. Chan \& C. Chinn (Eds.), The International Handbook of Collaborative Learning. New York: Routledge.

MacGregor, J., Tinto, V., \& Lindbald, J.H. (2001). Assessment of innovative efforts: Lessons from the learning community movement. In L. Suskie (Ed.), Assessment to Promote Deep Learning: Insight from AAH's 2000 and 1999 Assessment Conferences (pp. 41-48). Washington, D.C.: AAHE.

Maldonado, H., \& Pea, R. (2010). LET's GO! to the Creek: Co-design of water quality inquiry using mobile science collaboratories. Proceedings of the IEEE International Conference on Wireless, Mobile, and Ubiquitous Technologies in Education 2010 (pp. 81-87), Kaohsiung, Taiwan.

Mann, S., \& Reimann, P. (2007). Mobile technology as a mediating tool for learning in the convergences from technology, collaboration and curriculum perspectives. Proceedings of the International Conference on Mobile Learning 2007 (pp. 144-148), Melbourne, Australia.

Metcalf, D., Milrad, M., Cheek, D., Raasch, S., \& Hamilton, A. (2008). My Sports Pulse: Increasing student interest in STEM disciplines through sports themes, games and mobile technologies. Proceedings of the IEEE International Conference on Wireless, Mobile, and Ubiquitous Technology in Education 2008 (pp. 23-30), Beijing, China.

Milrad, M. (2008). Designing collaborative tangible spaces to support seamless learning. Paper presented at the Shareable Interfaces for Learning Workshop 2008, Brighton, UK.

http://shareitproject.org/uploads/25/Milrad_Share_IT_2008.doc

Miyata, H., Sannomiya, M., \& Suzuki, M. (2010). Development and evaluation of web-based mobile contents for logical thinking by teaching students 'how to think'. Mobile Learning and Organisation, 4(4), 391-406.

Naismith, L., Lonsdale, P., Vavoula, G., \& Sharples, M. (2004). Literature review in mobile technologies and learning (REPORT 11).

Ng, W., \& Nicholas, H. (2007). Ubiquitous learning with handhelds in schools. Proceedings of the International Conference on Mobile Learning 2007 (pp. 186-193), Melbourne, Australia.

Please cite:

Wong, L.-H., \& Looi, C.-K. (2011). What seams do we remove in mobile assisted seamless learning? A critical review of the literature. Computers \& Education, 57(4), 2364-2381. 
Norris, C., \& Soloway, E. (2002). Keynote speech. Paper presented at the IEEE International Workshop on Wireless and Mobile Technologies in Education 2002, Växjö, Sweden.

Norris, C., \& Soloway, E. (2004). Keynote speech. Paper presented at the International Conference on Intelligent Tutoring Systems 2004, Maceio, Brazil.

Obisat, F., \& Hattab, E. (2009). A proposed model for individualized learning through mobile technologies. Computers, 1(3), 125-132.

Ogata, H., Hui, G. L., Yin, C., Ueda, T., Oishi, Y., \& Yano, Y. (2008) . Loch: Supporting mobile language learning outside classrooms. Mobile Learning and Organisation, $2(3), 271-282$.

Otero, N., Milrad, M., Rogers, Y., Santos, A. J., Veríssimo, M., \& Torres, N. (2011). Challenges in designing seamless-learning scenarios: affective and emotional effects on external representations. Mobile Learning and Organisation, 5(1), $15-27$.

Patten, B., Arnedillo-Sánchez, I., \& Tangney, B. (2006). Designing collaborative, constructionist and contextual applications for handheld devices. Computers \& Education, 46(3), 294-308.

Pea, R., \& Maldonado, H. (2006). WILD for learning: Interacting through new computing devices, anytime, anywhere. In K. Sawyer (Ed.), Cambridge Handbook of Learning Sciences (pp. 427-442). New York, USA: Cambridge University Press.

Pear, J. J., Crone-Todd, D. E., Wirth, K., \& Simister, H. (2000). Assessment of thinking levels in students' answers. Academic Exchange Quarterly, 5(4), 94-98.

Pelletier, J., Reeve, R., \& Hallewood, C. (2006). Young children's knowledge building and literacy development through Knowledge Forum. Early Education and Development, $17(3), 323-346$.

Pham-Nguyen, C., \& Garlatti, S. (2008). Pervasive technology-enhanced learning system integrating working and learning situations. Proceedings of the International Conference on Information and Communication Technologies 2008 (pp. 1-6), Damascus, Syria.

Pintus, A., Carboni, D., Paddeu, G., Piras, A., \& Sanna, S. (2004). Mobile lessons: concept and applications for 'on-site' geo-referenced lessons. Proceedings of the International Conference on Mobile Learning 2004 (pp. 163-166), Rome, Italy.

Rogers, Y., Connelly, K., Hazlewood, W., \& Tedesco, L. (2010). Enhance learning: A study of how mobile devices can facilitate sensemaking. Personal and Ubiquitous Computing, 14(2), 111-124.

Rogers, Y., Connelly, K., Tedesco, L., Hazlewood, W., Kurtz, A., Hall, R. E., et al. (2007). Why it's worth the hassle: The value of in-situ studies when designing Ubicomp. Proceedings of the International Conference on Ubiquitous Computing 2007 (pp. 336-353), Innsbruck, Austria.

Rogers, Y., \& Price, S. (2008). The role of mobile devices in facilitating collaborative inquiry in situ. Resarch and Practice in Technology Enhanced Learning, 3(3), 209-229.

Please cite:

Wong, L.-H., \& Looi, C.-K. (2011). What seams do we remove in mobile assisted seamless learning? A critical review of the literature. Computers \& Education, 57(4), 2364-2381. 
Rogers, Y., \& Price, S. (2009). How mobile technologies are changing the way children learn. In A. Druin (Ed.), Mobile Technology for Children (pp. 3-22). Boston: Morgan Kaufmann.

Roschelle, J. (2003). Keynote paper: Unlocking the learning value of wireless mobile devices. Computer Assisted Learning, 19(3), 260-272.

Sánchez, J., \& Salinas, A. (2008). Science problem solving learning through mobile gaming. Proceedings of the International Conference on Entertainment and Media in the Ubiquitous Era 2008 (pp. 49-53), Tampere, Finland.

Schank, R. (1999). Dynamic Memory Revisited. Cambridge, UK: Cambridge University Press.

Seifert, T. A., Goodman, K. M., Lindsay, N., Jorgensen, J. D., Wolniak, G. C., Pascarella, E. T., et al. (2008). The effects of liberal arts experiences on liberal arts outcomes. Resarch in Higher Education, 49(2), 107-125.

Seow, P., Zhang, B., Chen, W., Looi, C.-K., \& Tan, N. (2009). Designing a seamless learning environment to learn reduce, reuse and recycle in environmental education. Mobile Learning and Organisation, 3(1), 60-83.

Sharples, M., Arnedillo-Sánchez, I., Milrad, M., \&Vavoula, G. (2009). Mobile learning: Small devices, big issues. In S. Ludvigsen, N. Balacheff, T. De Jong, A. Lazonder \& S. Barnes (Eds.), Technology-Enhanced Learning: Principles and Products (pp. 233-249): Springer Netherlands.

Sharples, M., Taylor, J., \& Vavoula, G. (2007). A theory of learning for the mobile age. In R. Andrews \& C. Haythornthwaite (Eds.), The Sage Handbook of E-learning Research (pp. 221-247). London: Sage.

Shih, J.-L., Chu, H.-C., Hwang, G.-J., \& Kinshuk. (2010). An investigation of attitudes of students and teachers about participating in a context-aware ubiquitous learning activity. British Journal of Educational Technology, 42(3), 373-394.

Shih, W.-C., \& Tseng, S.-S. (2009). A knowledge-based approach to retrieving teaching materials for context-aware learning. Educational Technology \& Society, 12(1), $82-106$.

Skop, E. (2008). Creating field trip-based learning communities. Geography, 107, $230-235$.

Smith, K., \& Northrop, K. (1998). The CLASS Course Design Model for web-based instruction. Paper presented at the Annual Conference on Distance Teaching and Learning 1998, Madison, WI.

So, H.-J., Kim, I., \& Looi, C.-K. (2008). Seamless mobile learning: Possibilities and challenges arising from the Singapore experience. Educational Technology International, 9(2), 97-121.

So, H.-J., Seow, P., \& Looi, C.-K. (2009). Location matters: Leveraging knowledge building with mobile devices and Web 2.0 technology. Interactive Learning Environment, $17(4), 367-382$.

Song, Y. (2007). Educational uses of handheld devices: What are the consequences? Techtrends, 51, 38-45.

Please cite:

Wong, L.-H., \& Looi, C.-K. (2011). What seams do we remove in mobile assisted seamless learning? A critical review of the literature. Computers \& Education, 57(4), 2364-2381. 
Spikol, D., \& Milrad, M. (2008). Physical activities and playful learning using mobile devices. Resarch and Practice in Technology Enhanced Learning, 3(3), 275-295.

Strauss, A., \& Corbin, J. (1990). Basics of Qualitative Research: Grounded Theory Procedures and Techniques. Newbury Park, CA: Sage.

Tan, T.-H., Liu, T.-Y., \& Chang, C.-C. (2007). Development and evaluation of an RFID-based ubiquitous learning environment for outdoor learning. Interactive Learning Environment, 15(3), 253-269.

Tinto, V. (1998). Learning communities: Building gateways to student success. The National Teaching and Learning Forum, 7, 1-11.

Uosaki, N., Li, M., Hou, B., Ogata, H., \& Yano, Y. (2010). Supporting English course using mobile devices in a seamless learning environment Workshop Proceedings of International Conference on Computers in Education 2010 (pp. 193-200). Putrajaya, Malaysia.

Vavoula, G., \& Sharples, M. (2009). Meeting the challenges in evaluating mobile learning: A 3-level evaluation framework. Mobile and Blended Learning, 1(2), $54-75$.

Vogel, D., Kennedy, D. M., Kuan, K., Kwok, R., \& Lai, J. (2007). Do mobile device applications affect learning? Proceedings of the Hawaii International Conference on System Sciences 2007 (pp. 4-12), Big Island, Hawaii.

Wang, J., \& Li, J. (2008). Research on mobile learning platform with device adapting ability based on agent. Proceedings of the International Conference on Computer Science and Software Engineering 2008 (pp. 933-936), Wuhan, China.

Wang, W., \& Wang, Z. (2008) . Leveraging on u-learning to nurture a society of learning. China Educational Technique \& Equipment, 2008(22), 33-35.

Weick, K. E. (1995). Sensemaking in organizations. Thousand Oaks, CA: Sage.

Wong, L.-H. (2010a). From facilitated seamless learning to self-directed seamless learning. Proceedings of the Global Chinese Conference on Computers in Education 2010 (pp. 33-40), Singapore.

Wong, L.-H. (2010b). Theme-based Invited Speech (CUMTEL). Paper presented at the International Conference on Computers in Education 2010, Putrajaya, Malaysia.

Wong, L.-H., Chen, W., Looi, C.-K., \& Zhang, B. (2010). Analysis of attributes of mobile learning activities: Two case studies of m-learning design. China Educational Technology, 2010(2), 7-15.

Wong, L.-H., Chen, W., Zhan, Y., \& Chin, C.-K. (in-press). Analysis of small group interactions in a seamless language learning environment: An artifact-oriented approach. Proceedings of the International Conference on Computer Supported Collaborative Learning 2011, Hong Kong, China.

Wong, L.-H., Chin, C.-K., Tan, C.-L., \& Liu, M. (2010). Students' personal and social meaning making in a Chinese idiom mobile learning environment. Educational Technology \& Society, 13(4), 15-26.

Please cite:

Wong, L.-H., \& Looi, C.-K. (2011). What seams do we remove in mobile assisted seamless learning? A critical review of the literature. Computers \& Education, 57(4), 2364-2381. 
Wong, L.-H., \& Looi, C.-K. (2010). Vocabulary learning by mobile-assisted authentic content creation and social meaning-making: Two case studies. Computer Assisted Learning, 26(5), 421-433.

Wyeth, P., Smith, H., Ng, K.H., Fitzpatrick, G., Luckin, R., Walker, K., et al. (2008). Learning through treasure hunting: The role of mobile devices. Proceedings of the International Conference on Mobile Learning 2008 (pp. 27-34), Algarve, Portugal.

Yang, S. J.H. (2006). Context aware ubiquitous learning environments for peer-to-peer collaborative learning. Educational Technology \& Society, 9(1), 188-201.

Yu, S. (2007). Development and prospect of three generations of mobile learning: Knowledge transfer, cognitive construction and situated cognition. China Educational Technology, 2007(6).

Yu, S., Yang, X., \& Cheng, G. (2009). Learning resource design and sharing in ubiquitous learning environment: The concept and architecture of learning cell. Open Education Research, 15(1), 47-53.

Zhang, B. H., Looi, C.-K., Seow, P., Chia, G., Wong, L.-H., Chen, W., et al. (2010). Deconstructing and reconstructing: Transforming primary science learning via a mobilized curriculum. Computers \& Education, 55(4), 1504-1523.

Zhang, H., \& Maesako, T. (2009). A framework of learner development ecosystem for designing a ubiquitous educational informational infrastructure. Software, $4(2), 124-131$.

Zhang, J., Scardamalia, M., Lamon, M., Messina, R., \& Reeve, R. (2007). Socio-cognitive dynamics of knowledge building in the work of 9- and 10-year-olds. Educational Technology Research and Development, 55(2), 117-145.

Zhao, X., \&Okamoto, T. (2011). Adaptive multimedia content delivery for context-aware u-learning. Mobile Learning and Organisation, 5(1), 46-63.

Please cite:

Wong, L.-H., \& Looi, C.-K. (2011). What seams do we remove in mobile assisted seamless learning? A critical review of the literature. Computers \& Education, 57(4), 2364-2381. 
Appendix 1:

(Legends: MSL dimensions in italics - as defined or described; MSL dimensions in bold - as incorporated in the actual MSL system or activity design)

$(\dagger$ denotes that the paper cited Chan et al. (2006))

\begin{tabular}{|c|c|c|c|c|c|c|c|c|c|c|c|}
\hline \multirow{2}{*}{$\begin{array}{l}\text { Citation or } \\
\text { research } \\
\text { project }\end{array}$} & \multirow{2}{*}{$\begin{array}{l}\text { Paper type / Brief } \\
\text { Description of the } \\
\text { content }\end{array}$} & \multicolumn{10}{|c|}{ MSL dimensions } \\
\hline & & $\begin{array}{l}\text { (MSL1) } \\
\text { Formal + informal } \\
\text { learning }\end{array}$ & $\begin{array}{l}\text { (MSL2) } \\
\text { Personal + } \\
\text { social } \\
\text { learning }\end{array}$ & $\begin{array}{l}\text { (MSL3) } \\
\text { Across } \\
\text { time }\end{array}$ & $\begin{array}{l}\text { (MSL4) } \\
\text { Across } \\
\text { locations }\end{array}$ & $\begin{array}{l}\text { (MSL5) } \\
\text { Ubiquitous } \\
\text { knowledge } \\
\text { access }\end{array}$ & $\begin{array}{l}\text { (MSL6) } \\
\text { Physical + } \\
\text { digital } \\
\text { spaces }\end{array}$ & $\begin{array}{l}\text { (MSL7) } \\
\text { Multiple } \\
\text { devices and } \\
\text { device } \\
\text { types }\end{array}$ & $\begin{array}{l}\text { (MSL8) } \\
\text { Switching } \\
\text { between } \\
\text { learning } \\
\text { tasks }\end{array}$ & $\begin{array}{l}\text { (MSL9) } \\
\text { Knowledge } \\
\text { synthesis }\end{array}$ & $\begin{array}{l}\text { (MSL10) } \\
\text { Multiple } \\
\text { pedagogical or } \\
\text { learning } \\
\text { activity models }\end{array}$ \\
\hline $\begin{array}{l}\text { (Chan, } \\
\text { Roschelle, et } \\
\text { al., 2006) }\end{array}$ & $\begin{array}{l}\text { Conceptual paper on 1:1 } \\
\text { TEL }\end{array}$ & Yes & Yes & Yes & Yes & $\begin{array}{l}\text { Yes (context- } \\
\text { aware) }\end{array}$ & Yes & Yes & No & No & No \\
\hline \multirow{2}{*}{$\begin{array}{l}\dagger(\text { Chan, } \\
\text { Chen, et al., } \\
\text { 2006) }\end{array}$} & \multirow{2}{*}{$\begin{array}{l}\text { Conceptual paper on } \\
\text { Profile Enhanced } \\
\text { Classroom Learning } \\
\text { (PECL) }\end{array}$} & Yes & Yes & Yes & Yes & No & Yes & $\mathrm{No}$ & No & $\mathrm{No}$ & $\mathrm{No}$ \\
\hline & & $\begin{array}{l}\text { No (Focusing on } \\
\text { teacher- } \\
\text { facilitated learning) }\end{array}$ & Yes & $\begin{array}{l}\text { No } \\
\text { (within } \\
\text { class } \\
\text { hours) }\end{array}$ & Yes & No & Yes & No & No & $\begin{array}{l}\text { Yes (prior } \\
+ \text { new) }\end{array}$ & No \\
\hline \multirow{2}{*}{$\begin{array}{l}\dagger(\text { S.-B. } \\
\text { Chang, et al., } \\
\text { 2006) }\end{array}$} & \multirow{2}{*}{$\begin{array}{l}\text { Conceptual paper on a } \\
\text { learning design strategy } \\
\text { "PER" }\end{array}$} & Yes & Yes & Yes & Yes & $\mathrm{No}$ & Yes & $\mathrm{No}$ & $\mathrm{No}$ & $\mathrm{No}$ & Yes \\
\hline & & $\begin{array}{l}\text { No (formal learning } \\
\text { only) }\end{array}$ & Yes & No & No & No & No & No & No & No & Yes \\
\hline $\begin{array}{l}\dagger \text { (Deng, et al., } \\
2006)\end{array}$ & $\begin{array}{l}\text { Conceptual paper on } \\
\text { Component Exchange } \\
\text { Community (NOT a } \\
\text { learning design but a } \\
\text { platform for } 1: 1 \text { TEL } \\
\text { research community to } \\
\text { share resources) }\end{array}$ & Yes & Yes & Yes & Yes & $\mathrm{No}$ & No & $\mathrm{No}$ & $\mathrm{No}$ & No & Yes \\
\hline \multirow[t]{2}{*}{ (Yang, 2006) } & \multirow{2}{*}{$\begin{array}{l}\text { System development (a } \\
\text { context aware ubiquitous } \\
\text { learning environment) }\end{array}$} & No & Yes & Yes & Yes & $\begin{array}{l}\text { Yes (context- } \\
\text { aware) }\end{array}$ & Yes & $\mathrm{No}$ & $\mathrm{No}$ & No & $\mathrm{No}$ \\
\hline & & Yes & Yes & Yes & Yes & $\begin{array}{l}\text { Yes } \\
\text { (context- } \\
\text { aware) }\end{array}$ & Yes & $\begin{array}{l}\text { Yes (PDA } \\
+ \text { PC) }\end{array}$ & No & $\begin{array}{l}\text { Yes (past + } \\
\text { current } \\
\text { context) }\end{array}$ & No \\
\hline $\begin{array}{l}\text { (C.-S. Chang } \\
\text { \& Chen, } \\
\text { 2007) }\end{array}$ & $\begin{array}{l}\text { System development } \\
\text { "Ubiquitous Learning } \\
\text { Grid" }\end{array}$ & Yes & Yes & Yes & Yes & Yes & Yes & Yes & Yes & $\begin{array}{l}\text { Yes (prior } \\
+ \text { new / } \\
\text { abstract + } \\
\text { concrete) }\end{array}$ & No \\
\hline $\begin{array}{l}\text { (Chapel, } \\
\text { 2008) }\end{array}$ & $\begin{array}{l}\text { Deployment of a } 1: 1 \\
\text { program in a university }\end{array}$ & Yes & Yes & Yes & Yes & Yes & Yes & No & No & No & No \\
\hline $\begin{array}{l}\text { (H.-J. Huang, } \\
\text { 2007) }\end{array}$ & $\begin{array}{l}\text { System development + } \\
\text { pilot study (a mobile } \\
\text { forum "StudentPartner") }\end{array}$ & $\begin{array}{l}\text { Yes (but greater } \\
\text { emphasis on informal } \\
\text { learning) }\end{array}$ & Yes & Yes & Yes & $\begin{array}{l}\text { Yes } \\
\text { (Internet } \\
\text { info \& }\end{array}$ & Yes & $\begin{array}{l}\text { Yes (PDA } \\
+ \text { PC) }\end{array}$ & No & No & No \\
\hline
\end{tabular}

Please cite:

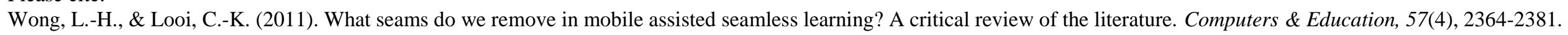




\begin{tabular}{|c|c|c|c|c|c|c|c|c|c|c|c|}
\hline & & & & & & $\begin{array}{l}\text { forum } \\
\text { access) }\end{array}$ & & & & & \\
\hline $\begin{array}{l}\text { (Y.-T. Huang, } \\
\text { et al., 2007) }\end{array}$ & $\begin{array}{l}\text { System development of a } \\
\text { mobile video Q\&A } \\
\text { system + pilot study }\end{array}$ & Yes & Yes & Yes & Yes & $\begin{array}{l}\text { Yes (online } \\
\text { video } \\
\text { access) }\end{array}$ & No & No & No & No & No \\
\hline $\begin{array}{l}\dagger(\text { Kerawalla, } \\
\text { et al., 2007) }\end{array}$ & $\begin{array}{l}\text { Deployment (focusing on } \\
\text { home-school link) }\end{array}$ & Yes & $\begin{array}{l}\text { Yes (kids } \\
\& \\
\text { parents) }\end{array}$ & Yes & Yes & $\begin{array}{l}\text { Yes } \\
\text { (Internet } \\
\text { info access) }\end{array}$ & Yes & No & No & $\begin{array}{l}\text { Yes } \\
\text { (abstract + } \\
\text { concrete) }\end{array}$ & No \\
\hline $\begin{array}{l}\text { (Khan \& Zia, } \\
\text { 2007) }\end{array}$ & $\begin{array}{l}\text { Conceptual paper on a } \\
\text { pervasive learning } \\
\text { environment }\end{array}$ & Yes & Yes & Yes & Yes & $\begin{array}{l}\text { Yes } \\
\text { (context- } \\
\text { aware) }\end{array}$ & Yes & No & No & No & No \\
\hline $\begin{array}{l}\dagger(\text { Lai, et al., } \\
2007)\end{array}$ & $\begin{array}{l}\text { System development of } \\
\text { "learning passport" + } \\
\text { pilot study }\end{array}$ & Yes & No & Yes & Yes & No & Yes & $\begin{array}{l}\text { Yes (PDA } \\
+ \text { PC) }\end{array}$ & No & $\begin{array}{l}\text { Yes (prior } \\
+ \text { new) }\end{array}$ & Yes \\
\hline $\begin{array}{l}\text { (Lee, et al., } \\
2007)\end{array}$ & $\begin{array}{l}\text { System development of a } \\
\text { context-aware adaptive } \\
\text { u-learning system }\end{array}$ & No & No & Yes & Yes & $\begin{array}{l}\text { Yes } \\
\text { (context- } \\
\text { aware) }\end{array}$ & No & No & No & No & No \\
\hline $\begin{array}{l}(\mathrm{Ng} \& \\
\text { Nicholas, } \\
2007)\end{array}$ & $\begin{array}{l}\text { Conceptual paper on a } \\
\text { "theoretical framework } \\
\text { for ubiquitous (seamless) } \\
\text { learning" }\end{array}$ & Yes & Yes & Yes & Yes & $\begin{array}{l}\text { Yes (Internet } \\
\text { info access) }\end{array}$ & Yes & Yes & $\mathrm{No}$ & $\begin{array}{l}\text { Yes (prior } \\
+ \text { new) }\end{array}$ & $\mathrm{No}$ \\
\hline $\begin{array}{l}\text { (Tan, et al., } \\
\text { 2007) }\end{array}$ & $\begin{array}{l}\text { System development and } \\
\text { pilot study - EULER } \\
\text { project }\end{array}$ & $\begin{array}{l}\text { No (mainly formal } \\
\text { learning) }\end{array}$ & Yes & $\begin{array}{l}\text { Yes }(3- \\
\text { week } \\
\text { lesson) }\end{array}$ & Yes & Yes & Yes & No & No & No & Yes \\
\hline $\begin{array}{l}\text { (Vogel, et al., } \\
2007 \text { ) }\end{array}$ & $\begin{array}{l}\text { Pilot study of } 1: 1 \\
\text { program in a university }\end{array}$ & Yes & Yes & Yes & Yes & $\begin{array}{l}\text { Yes } \\
\text { (Internet } \\
\text { info access) }\end{array}$ & Yes & $\begin{array}{l}\text { Yes (PDA } \\
+ \text { PC) }\end{array}$ & No & No & No \\
\hline $\begin{array}{l}\text { (N.-S. Chen, } \\
\text { et al., 2008) }\end{array}$ & $\begin{array}{l}\text { System development of } \\
\text { the GroupNet } \\
\text { infrastructure to support } \\
\text { collaborative u-learning }\end{array}$ & $\begin{array}{l}\text { No (essentially } \\
\text { "formal learning in } \\
\text { informal setting") }\end{array}$ & $\begin{array}{l}\text { Yes (but } \\
\text { more } \\
\text { social } \\
\text { learning- } \\
\text { inclined) }\end{array}$ & No & Yes & $\begin{array}{l}\text { Yes } \\
\text { (context- } \\
\text { aware) }\end{array}$ & Yes & No & No & No & No \\
\hline $\begin{array}{l}\text { (Chiu, et al., } \\
\text { 2008) }\end{array}$ & $\begin{array}{l}\text { Conceptual framework: } \\
\text { An evaluation method } \\
\text { for u-learning }\end{array}$ & $\mathrm{No}$ & $\mathrm{No}$ & Yes & Yes & Yes & $\mathrm{No}$ & No & No & $\mathrm{No}$ & No \\
\hline $\begin{array}{l}\text { (Hwang, et } \\
\text { al., 2008) }\end{array}$ & $\begin{array}{l}\text { Conceptual paper on } \\
\text { context-aware u-learning }\end{array}$ & No & No & Yes & Yes & $\begin{array}{l}\text { Yes (context- } \\
\text { aware) }\end{array}$ & No & Yes & No & $\mathrm{No}$ & No \\
\hline \multirow{2}{*}{$\begin{array}{l}\dagger \text { (Lin, et al., } \\
2008)\end{array}$} & \multirow{2}{*}{$\begin{array}{l}\text { Conceptual paper on a } \\
\text { learning design }\end{array}$} & Yes & Yes & Yes & Yes & No & No & $\mathrm{No}$ & $\mathrm{No}$ & $\mathrm{No}$ & $\mathrm{No}$ \\
\hline & & $\begin{array}{l}\text { Yes (internship - } \\
\text { "formal learning in } \\
\text { informal setting") }\end{array}$ & Yes & Yes & Yes & $\begin{array}{l}\text { Yes } \\
\text { (Internet } \\
\text { info access) }\end{array}$ & Yes & $\begin{array}{l}\text { Yes (PDA } \\
+ \text { PC) }\end{array}$ & No & $\begin{array}{l}\text { Yes } \\
\text { (abstract + } \\
\text { concrete) }\end{array}$ & No \\
\hline $\begin{array}{l}\text { (Metcalf, et } \\
\text { al., 2008) }\end{array}$ & $\begin{array}{l}\text { Conceptual paper on } \\
\text { learning activity design - } \\
\text { My Sports Pulse }\end{array}$ & $\begin{array}{l}\text { Yes (activities take } \\
\text { place in informal } \\
\text { setting but students }\end{array}$ & No & Yes & Yes & Yes & No & No & No & Yes & No \\
\hline
\end{tabular}

Please cite:

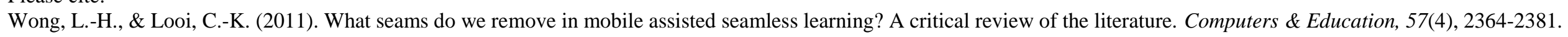




\begin{tabular}{|c|c|c|c|c|c|c|c|c|c|c|c|}
\hline & & $\begin{array}{l}\text { may need to retrieve } \\
\text { knowledge learned in } \\
\text { formal classes) }\end{array}$ & & & & & & & & & \\
\hline \multirow{2}{*}{$\begin{array}{l}\dagger \text { (Milrad, } \\
\text { 2008) /(Kurti, } \\
\text { et al., 2008) }\end{array}$} & \multirow{2}{*}{$\begin{array}{l}\text { System development }+ \\
\text { learning activity design }+ \\
\text { pilot studies (AMULETS } \\
\text { project) }\end{array}$} & Yes & Yes & Yes & Yes & Yes & Yes & No & No & No & No \\
\hline & & $\begin{array}{l}\text { Yes (formal learning } \\
\text { + informal learning } \\
\text { [“formal learning in } \\
\text { informal setting”]) }\end{array}$ & Yes & $\begin{array}{l}\text { No } \\
\text { (one-off } \\
\text { activity) }\end{array}$ & $\begin{array}{l}\text { Yes } \\
\text { (classroom } \\
- \text { site - } \\
\text { classroom) } \\
\end{array}$ & $\begin{array}{l}\text { Yes } \\
\text { (context- } \\
\text { aware) }\end{array}$ & Yes & $\begin{array}{l}\text { Yes (Case } \\
\text { Study 2: } \\
\text { phones + } \\
\text { PC) }\end{array}$ & Yes & $\begin{array}{l}\text { Yes (Case } \\
\text { Study 2: } \\
\text { cross- } \\
\text { Subjects) }\end{array}$ & Yes \\
\hline $\begin{array}{l}\dagger(\text { Ogata, et } \\
\text { al., 2008) }\end{array}$ & $\begin{array}{l}\text { System development }+ \\
\text { learning activity design }+ \\
\text { pilot study (LOCH } \\
\text { project) }\end{array}$ & Yes & Yes & Yes & $\begin{array}{l}\text { Yes } \\
\text { (classroom } \\
- \text { site }- \\
\text { classroom) }\end{array}$ & $\begin{array}{l}\text { Yes } \\
\text { (Internet } \\
\text { info access) }\end{array}$ & Yes & No & Yes & No & Yes \\
\hline $\begin{array}{l}\text { (Pham-Nguye } \\
\text { n \& Garlatti, } \\
\text { 2008) }\end{array}$ & $\begin{array}{l}\text { Conceptual paper on a } \\
\text { context-aware workplace } \\
\text { learning system }\end{array}$ & Yes & Yes & Yes & Yes & $\begin{array}{l}\text { Yes } \\
\text { (context- } \\
\text { aware) }\end{array}$ & Yes & No & Yes & $\begin{array}{l}\text { Yes (inter- } \\
\text { disciplinar } \\
\text { y) }\end{array}$ & No \\
\hline $\begin{array}{l}\text { (Rogers \& } \\
\text { Price, 2008) / } \\
\text { (Rogers, et al., } \\
2010)\end{array}$ & $\begin{array}{l}2 \text { case studies: Ambient } \\
\text { Wood \& LillyPad }\end{array}$ & $\begin{array}{l}\text { Yes (formal learning } \\
\text { + informal learning } \\
\text { ["formal learning in } \\
\text { informal setting"]) }\end{array}$ & Yes & $\begin{array}{l}\text { No } \\
\text { (one-off } \\
\text { activity) }\end{array}$ & Yes & $\begin{array}{l}\text { Yes } \\
\text { (context- } \\
\text { aware) }\end{array}$ & Yes & Yes & Yes & $\begin{array}{l}\text { Yes (prior } \\
+ \text { new } \\
\text { knowledge } \\
\text { ) }\end{array}$ & Yes \\
\hline $\begin{array}{l}\dagger \text { †(Sánchez \& } \\
\text { Salinas, 2008) }\end{array}$ & $\begin{array}{l}\text { System development + } \\
\text { learning activity design }+ \\
\text { pilot studies (“ABTm } \\
\text { project") }\end{array}$ & Yes & Yes & Yes & Yes & No & Yes & No & No & $\begin{array}{l}\text { Yes } \\
\text { (abstract + } \\
\text { concrete) }\end{array}$ & Yes \\
\hline $\begin{array}{l}\text { (So, et al., } \\
2008)\end{array}$ & $\begin{array}{l}\text { Conceptual paper on } \\
\text { seamless learning }+2 \\
\text { case studies }\end{array}$ & Yes & Yes & Yes & Yes & $\mathrm{No}$ & Yes & $\mathrm{No}$ & Yes & Yes & $\mathrm{No}$ \\
\hline \multirow{2}{*}{$\begin{array}{l}\dagger(\text { Spikol \& } \\
\text { Milrad, 2008) }\end{array}$} & \multirow{2}{*}{$\begin{array}{l}\text { Learning activity design } \\
\text { + pilot study of mobile } \\
\text { outdoor games } \\
\text { ("Skattjakt") }\end{array}$} & Yes & Yes & Yes & Yes & $Y e s$ & Yes & $\mathrm{No}$ & $\mathrm{No}$ & $\mathrm{No}$ & $\mathrm{No}$ \\
\hline & & $\begin{array}{l}\text { No (informal } \\
\text { learning, which is } \\
\text { "formal learning in } \\
\text { informal setting") }\end{array}$ & Yes & $\begin{array}{l}\text { No } \\
\text { (one-off } \\
\text { activity) }\end{array}$ & $\begin{array}{l}\text { Yes } \\
\text { (college } \\
\text { campus) }\end{array}$ & $\begin{array}{l}\text { Yes } \\
\text { (context- } \\
\text { aware) }\end{array}$ & Yes & No & Yes & No & No \\
\hline $\begin{array}{l}\text { (J. Wang \& } \\
\mathrm{Li}, \text { 2008) }\end{array}$ & $\begin{array}{l}\text { System design (for } \\
\text { adaptive mobile learning } \\
\text { resource retrieval) }\end{array}$ & No & $\begin{array}{l}\text { No } \\
\text { (personal } \\
\text { learning } \\
\text { only) }\end{array}$ & Yes & Yes & $\begin{array}{l}\text { Yes (online } \\
\text { learning } \\
\text { resources) }\end{array}$ & $\begin{array}{l}\text { No } \\
\text { (online } \\
\text { learning } \\
\text { only) }\end{array}$ & Yes & No & No & No \\
\hline $\begin{array}{l}\dagger(\text { W. Wang \& } \\
\text { Wang, 2008) }\end{array}$ & $\begin{array}{l}\text { Conceptual paper on } \\
\mathrm{u} \text {-learning in general }\end{array}$ & $\mathrm{No}$ & $\mathrm{No}$ & Yes & Yes & Yes & $\mathrm{No}$ & $\mathrm{No}$ & No & No & No \\
\hline $\begin{array}{l}\dagger(\text { Wyeth, et } \\
\text { al., 2008) }\end{array}$ & $\begin{array}{l}\text { Learning activity design } \\
\text { [“My Mobile Mission" } \\
\text { (M3)] }\end{array}$ & $\begin{array}{l}\text { No (essentially } \\
\text { "formal learning in } \\
\text { informal setting") }\end{array}$ & Yes & $\begin{array}{l}\text { No } \\
\text { (one-off } \\
\text { activity) } \\
\end{array}$ & $\begin{array}{l}\text { Yes (M3 } \\
\text { HQ - site - } \\
\text { M3 HQ) }\end{array}$ & No & No & $\begin{array}{l}\text { Yes (PDA } \\
+ \text { iPod) }\end{array}$ & Yes & No & Yes \\
\hline $\begin{array}{l}\text { (Bick \& } \\
\text { Pawlowski, } \\
\text { 2009) }\end{array}$ & $\begin{array}{l}\text { System development (a } \\
\text { context-aware ubiquitous } \\
\text { environment for business } \\
\text { knowledge management }\end{array}$ & $\begin{array}{l}\text { No (essentially } \\
\text { "formal learning in } \\
\text { informal setting") }\end{array}$ & Yes & No & $\begin{array}{l}\text { No (within } \\
\text { the } \\
\text { business } \\
\text { premise) }\end{array}$ & $\begin{array}{l}\text { Yes } \\
\text { (context- } \\
\text { aware) }\end{array}$ & Yes & No & Yes & No & No \\
\hline
\end{tabular}

Please cite:

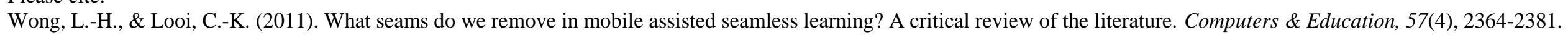




\begin{tabular}{|c|c|c|c|c|c|c|c|c|c|c|c|}
\hline & and learning) & & & & & & & & & & \\
\hline $\begin{array}{l}\text { (Chu, et al., } \\
\text { 2009) }\end{array}$ & $\begin{array}{l}\text { System design + pilot } \\
\text { study (context-aware } \\
\text { problem-based learning) }\end{array}$ & $\begin{array}{l}\text { No (essentially } \\
\text { formal setting) }\end{array}$ & Yes & Yes & Yes & $\begin{array}{l}\text { Yes } \\
\text { (context- } \\
\text { aware; web } \\
\text { access) }\end{array}$ & Yes & No & Yes & No & Yes \\
\hline $\begin{array}{l}\text { †(Kukulska-H } \\
\text { ulme, et al., } \\
\text { 2009) }\end{array}$ & Literature review & $\mathrm{No}$ & Yes & No & Yes & $\begin{array}{l}\text { Yes (context- } \\
\text { aware) }\end{array}$ & Yes & No & No & No & No \\
\hline $\begin{array}{l}\text { (Li, et al., } \\
2009)\end{array}$ & $\begin{array}{l}\text { Literature review }+ \\
\text { System development }- \\
\text { Smart Classroom (a } \\
\text { u-learning system that do } \\
\text { not involve mobile } \\
\text { device) }\end{array}$ & Yes & Yes & Yes & Yes & $\begin{array}{l}\text { Yes (context- } \\
\text { aware) }\end{array}$ & Yes & Yes & $\mathrm{No}$ & $\mathrm{No}$ & $\mathrm{No}$ \\
\hline $\begin{array}{l}\text { (Liao, et al., } \\
\text { 2009) }\end{array}$ & $\begin{array}{l}\text { System development + } \\
\text { pilot study }\end{array}$ & Yes & No & Yes & Yes & $\begin{array}{l}\text { Yes } \\
\text { (context- } \\
\text { aware) }\end{array}$ & No & Yes & Yes & No & No \\
\hline $\begin{array}{l}\text { (Miyata, et al., } \\
\text { 2010) }\end{array}$ & $\begin{array}{l}\text { System development + } \\
\text { pilot study }\end{array}$ & $\begin{array}{l}\text { No (formal } \\
\text { learning-centric) }\end{array}$ & Yes & $\begin{array}{l}\text { No } \\
\text { (one-off } \\
\text { activity) }\end{array}$ & $\begin{array}{l}\text { No } \\
\text { (in-class } \\
\text { only) }\end{array}$ & No & Yes & No & No & No & No \\
\hline $\begin{array}{l}\text { (Obisat \& } \\
\text { Hattab, 2009) }\end{array}$ & $\begin{array}{l}\text { Conceptual paper on a } \\
\text { mobile learning model }\end{array}$ & No & $\begin{array}{l}\text { No } \\
\text { (personal } \\
\text { learning- } \\
\text { centric) }\end{array}$ & Yes & Yes & No & Yes & No & No & No & $\begin{array}{l}\text { Yes (learning } \\
+ \text { assessment) }\end{array}$ \\
\hline $\begin{array}{l}\dagger(\text { Rogers \& } \\
\text { Price, 2009) }\end{array}$ & Conceptual paper & Yes & Yes & Yes & Yes & No & Yes & $\mathrm{No}$ & $\mathrm{No}$ & $\mathrm{No}$ & $\mathrm{No}$ \\
\hline $\begin{array}{l}\dagger(\text { Seow, et al., } \\
2009)\end{array}$ & $\begin{array}{l}\text { Learning activity design } \\
+ \text { pilot study (“3R" } \\
\text { project) }\end{array}$ & $\begin{array}{l}\text { Yes (formal learning } \\
\text { + "learning in } \\
\text { informal context") }\end{array}$ & Yes & Yes & $\begin{array}{l}\text { Yes } \\
\text { (classroom } \\
- \text { site - } \\
\text { classroom) }\end{array}$ & No & Yes & No & No & No & Yes \\
\hline $\begin{array}{l}\dagger(\text { Sharples, et } \\
\text { al., 2009) }\end{array}$ & $\begin{array}{l}\text { Conceptual papers + case } \\
\text { studies [The analysis in } \\
\text { this row is pertaining to } \\
\text { case study 1: } \\
\text { MyArtsSpace] }\end{array}$ & Yes & Yes & Yes & $\begin{array}{l}\text { Yes } \\
\text { (classroom } \\
- \text { site - } \\
\text { classroom) }\end{array}$ & No & Yes & No & Yes & No & Yes \\
\hline $\begin{array}{l}\text { (So, et al., } \\
2009 \text { ) }\end{array}$ & $\begin{array}{l}\text { Learning activity design } \\
\text { + pilot study } \\
\text { ("Chinatown } 1.0 \& \text { \& } 2.0 " \text { ") }\end{array}$ & Yes & Yes & Yes & $\begin{array}{l}\text { Yes } \\
\text { (classroom } \\
\text { - site - } \\
\text { home) }\end{array}$ & $\begin{array}{l}\text { Yes } \\
\text { (context- } \\
\text { aware) }\end{array}$ & Yes & $\begin{array}{l}\text { Yes (PDA } \\
+ \text { PC) }\end{array}$ & No & $\begin{array}{l}\text { Yes } \\
\text { (abstract + } \\
\text { concrete) }\end{array}$ & Yes \\
\hline $\begin{array}{l}\text { (W.-C. Shih \& } \\
\text { Tseng, 2009) }\end{array}$ & $\begin{array}{l}\text { System development + } \\
\text { pilot studies }\end{array}$ & $\begin{array}{l}\text { Yes (formal learning } \\
\text { + "learning in } \\
\text { informal context") }\end{array}$ & Yes & $\begin{array}{l}\text { No } \\
\text { (one-off } \\
\text { activity) }\end{array}$ & $\begin{array}{l}\text { No (school } \\
\text { compound } \\
\text { only) }\end{array}$ & $\begin{array}{l}\text { Yes } \\
\text { (context- } \\
\text { aware) }\end{array}$ & Yes & No & No & No & Yes \\
\hline $\begin{array}{l}\dagger(\mathrm{Yu}, \text { et al., } \\
2009)\end{array}$ & $\begin{array}{l}\text { Conceptual paper on an } \\
\text { u-learning technical }\end{array}$ & $\begin{array}{l}\text { No (essentially } \\
\text { informal learning) }\end{array}$ & Yes & Yes & Yes & $\begin{array}{l}\text { Yes (context- } \\
\text { aware) }\end{array}$ & Yes & No & No & No & No \\
\hline
\end{tabular}

Please cite:

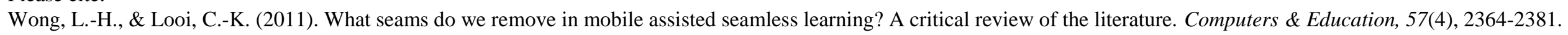




\begin{tabular}{|c|c|c|c|c|c|c|c|c|c|c|c|}
\hline & framework & & & & & & & & & & \\
\hline $\begin{array}{l}\dagger(\text { H. Zhang \& } \\
\text { Maesako, } \\
\text { 2009) }\end{array}$ & $\begin{array}{l}\text { Conceptual paper on a } \\
\text { u-learning design } \\
\text { framework }\end{array}$ & $\begin{array}{l}\text { Yes (though more } \\
\text { formal } \\
\text { learning-oriented) }\end{array}$ & Yes & Yes & Yes & $\begin{array}{l}\text { Yes } \\
\text { (Internet } \\
\text { info access) }\end{array}$ & Yes & No & Yes & No & Yes \\
\hline $\begin{array}{l}\text { (Bentley, et } \\
\text { al., 2010) }\end{array}$ & $\begin{array}{l}\text { University programme } \\
\text { evaluation }\end{array}$ & Yes & Yes & $\mathrm{No}$ & $\mathrm{No}$ & $\mathrm{No}$ & Yes & $\mathrm{No}$ & No & $\mathrm{No}$ & No \\
\hline $\begin{array}{l}\text { (El-Bishouty, } \\
\text { et al., 2010) }\end{array}$ & $\begin{array}{l}\text { System design + pilot } \\
\text { study (TSUL } \\
\text { environment) }\end{array}$ & Yes & Yes & Yes & Yes & $\begin{array}{l}\text { Yes } \\
\text { (Context- } \\
\text { aware) }\end{array}$ & Yes & No & No & No & No \\
\hline $\begin{array}{l}\text { †(Looi, et al., } \\
2010) /(\mathrm{W} . \\
\text { Chen, et al., } \\
\text { 2010) }\end{array}$ & $\begin{array}{l}\text { Conceptual paper on a } \\
\text { sustainable seamless } \\
\text { learning model }\end{array}$ & Yes & Yes & Yes & Yes & $\begin{array}{l}\text { Yes } \\
\text { (Internet } \\
\text { info access) }\end{array}$ & Yes & No & Yes & Yes & Yes \\
\hline $\begin{array}{l}\dagger \text { (Maldonado } \\
\& \text { Pea, 2010) }\end{array}$ & $\begin{array}{l}\text { Learning activity design } \\
\text { + pilot study ("LET's } \\
\text { Go! Project") }\end{array}$ & $\begin{array}{l}\text { Yes (formal learning } \\
\text { + "learning in } \\
\text { informal context") }\end{array}$ & Yes & Yes & Yes & $\begin{array}{l}\text { Yes } \\
\text { (context- } \\
\text { aware) }\end{array}$ & Yes & $\begin{array}{l}\text { Yes(smart- } \\
\text { phone + } \\
\text { PC) }\end{array}$ & Yes & No & No \\
\hline $\begin{array}{l}\text { (J.-L. Shih, et } \\
\text { al., 2010) }\end{array}$ & $\begin{array}{l}\text { Learning activity design } \\
+ \text { pilot study }\end{array}$ & $\begin{array}{l}\text { No (essentially } \\
\text { "formal learning in } \\
\text { informal setting") }\end{array}$ & No & $\begin{array}{l}\text { No } \\
\text { (one-off } \\
\text { activity) }\end{array}$ & $\begin{array}{l}\text { No (school } \\
\text { compound } \\
\text { only) }\end{array}$ & $\begin{array}{l}\text { Yes } \\
\text { (context- } \\
\text { aware) }\end{array}$ & Yes & No & No & No & No \\
\hline \multirow{2}{*}{$\begin{array}{l}\dagger(\text { Uosaki, et } \\
\text { al., 2010) }\end{array}$} & \multirow{2}{*}{$\begin{array}{l}\text { Learning environment } \\
\text { design + pilot study } \\
\text { (seamless vocabulary } \\
\text { learning) }\end{array}$} & Yes & $\mathrm{No}$ & Yes & Yes & $\mathrm{No}$ & No & $\mathrm{No}$ & Yes & $\mathrm{No}$ & $\mathrm{No}$ \\
\hline & & Yes & Yes & Yes & Yes & Yes & $\begin{array}{l}\text { No } \\
\text { (essential- } \\
\text { ly digital) }\end{array}$ & $\begin{array}{l}\text { Yes (PDA } \\
+ \text { PC) }\end{array}$ & No & $\begin{array}{l}\text { Yes (prior } \\
+ \text { new) }\end{array}$ & Yes \\
\hline $\begin{array}{l}\text { †(Wong, } \\
\text { Chin, et al., } \\
\text { 2010) / (Wong } \\
\text { \& Looi, 2010) }\end{array}$ & $\begin{array}{l}\text { Learning activity design } \\
\text { + pilot study ("Move, } \\
\text { Idioms!") }\end{array}$ & Yes & Yes & Yes & Yes & No & Yes & $\begin{array}{l}\text { Yes } \\
\text { (smart- } \\
\text { phone + } \\
\text { PC) }\end{array}$ & No & $\begin{array}{l}\text { Yes (prior } \\
+ \text { new / } \\
\text { abstract }+ \\
\text { concrete) }\end{array}$ & Yes \\
\hline $\begin{array}{l}\text { (Zhao \& } \\
\text { Okamoto, } \\
\text { 2011) }\end{array}$ & $\begin{array}{l}\text { System design + pilot } \\
\text { study (an adaptive } \\
\text { content delivery system } \\
\text { for u-learning) }\end{array}$ & No & Yes & Yes & Yes & $\begin{array}{l}\text { Yes } \\
\text { (context- } \\
\text { aware) }\end{array}$ & Yes & $\begin{array}{l}\text { Yes } \\
\text { (mobile } \\
\text { devices + } \\
\text { PC) } \\
\end{array}$ & No & No & No \\
\hline $\begin{array}{l}\dagger(\text { Otero, et } \\
\text { al., 2011) }\end{array}$ & Conceptual paper & Yes & Yes & No & Yes & Yes & Yes & No & No & $\begin{array}{l}\text { Yes } \\
\text { (abstract }+ \\
\text { concrete) }\end{array}$ & No \\
\hline
\end{tabular}

Please cite:

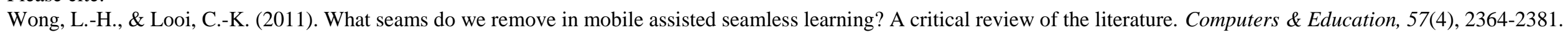

